\title{
From mammoth to fox: functional identification of Eliseevichi 1 within Upper Pleniglacial settlements of the the Desna valley
}

\begin{abstract}
INTRODUCTION
The paper examines the faunal record in the Desna valley (Russia, Ukraine), a tributary of the Dnieper, during the end of the second part of the Upper Pleniglacial (20 000 - 14000 BP). We carried a zooarchaeological study of the large mammal remains from Eliseevichi 1 excavated in 1935-36 by K.M. Polikarpovich (1968). Our aim is to compare the results of this analysis with other sites of the area during this period: Timonovka 1 and 2, Suponevo, Bugorok, Buzhenka 2, Chulatovo 1 and 2, and Mezin (Figure 1).
\end{abstract}

The end of the second part of the Upper Pleniglacial is marked by alternating cold periods (Pomerania-Vepsovo and Oldest Dryas) with moraines and periods of warming (organogenic deposits) (a little warming period before Oldest Dryas and the Bølling-Allerød oscillation) (Haesaerts et al., 2003). Deglaciation took place under very continental conditions with mild summers and cold winters. The wettest periods alternating with progressive levels of warming caused a shrinkage phenomenon of the front of the ice sheet, releasing new territories. Around 13,000 BP, gradually, the forest cover developed, and large herds disappeared. It is interesting to know what happened just before this important climatic change.

During this period the late Epigravettian culture was present in the Dnieper basin.

On the one hand two facies were described, the Mezinian and Eliseevichian (Djindjian et al., 1999). The Mezinian (Mezin, Mezhirich, Dobranichevka, Gontsy) concerns the lower basin of the Desna where sites are characterized by dwellings structures in mammoth bones and pits. The industry is homogenous, quite simple, tools are made on blades, composed of burins, scrapers, and backed bladelets. Objects in bone and ivory are numerous (points, needles, bâtons percés, awls). Portable art and ornaments are known such as schematic anthropomorphic statuettes, pendants, bracelets, with many engraved geometric patterns.
The Eliseevichian (Eliseevichi, Yudinovo, Timonovka, Suponevo, Chulatovo) is quite similar, but it is characterized by the predominance of burins, and particular artistic pieces such as churingas, and more realistic female statuettes. On the other hand, it is one culture, the Eastern Epigravettian characterized by four local versions, Mezinian, Ovruchian, Mezhirichian and Yudinovian). Two single series coexist with this culture: Eliseevichi 1 and Zhuravka (Nuzhnyi, 2006).

So the present contribution concentrates on patterns of faunal diversity and on human activities.

\section{MATERIAL AND METHODS}

We studied the faunal material discovered by K.M. Polikarpovich from Eliseevichi 1 in 1935-36, curated in Peter the Great Museum of Anthropology and Ethnography (Kunstkamera) and in the Zoological Institute of the Russian Academy in Saint-Petersburg (Russia) (Demay et al., in prep.) (Figure 3).

Concerning zooarchaeological methods, we used quantitative units after Poplin (1976) and Lyman (2008):

NR: number of remains.

NRt: total number of remains

MNE: minimum number of elements

cMNI: Minimum Number of Individuals by combination of parameters such as reassemblies, pairings, age and sex.

Unid:: unidentified

Ps: percentage survivorship, per elements, anatomical region or species. It takes into account the MAU (Minimum Animal Unit)

Ps = MNE . $100 /($ Qsp x MNI max $)=$ MAU . $100 /$ MNI max

We combined our faunal data about Eliseevichi 1 with Polikarpovich's ones (Polikarpovich, 1968; Velichko et al., 1997). Concerning of other sites we used data from Timonovka 1 and 2 (Gorodtzov, 1935; Gromov, 1948; Velichko et al., 1977, 
Grekhova, 1970; 1971), Suponevo (Shovkoplias, 1950; 1951; Gromov, 1948; Velichko, 1961; Sergin 2003), Yudinovo (Polikarpovich, 1968; Budko, 1966; 1967; 1969; Sablin, 2014), Chulatovo 1 (Pidoplichko, 1947; Boriskovski, 1953), Chulatovo 2 (Voevodski, 1952b; Boriskovski, 1953) and Mezin (Boriskovski 1953; Shovkoplias, 1965; Pidoplichko, 1969). New studies were provided, for instance in Yudinovo (Germonpré et al., 2008). However, to compare them, we only take in account faunal counting synthesized by O. Soffer (1985a) because the way to process to faunal count is actually somewhat different.

We used three paleoenvironmental method based on mammals.

Ecological diagrams (Andrews et al., 1979; Faure and Guérin, 1984) assess paleoecological diversity according to taxonomic diversity, body mass, diet and locomotion. Data are expressed by histograms, in terms of percentage of species.

Cenograms are based on average adult weight of mammalian species within a terrestrial area (Figure 2): $\mathrm{x}$-axis species in decreasing order of weight and $y$-axis neperian logarithm of their weight. They draw conclusions about relative humidity and level of tree cover (Legendre, 1986; Palombo and Giovinazzo, 2004). We removed carnivores and chiropters after $\mathrm{S}$. Montuire (1994). Two regression lines are calculated, for the mammals heavier than 500 grams and for the ones below 500 grams.

Diversity indexes are mathematical measures of species diversity in a community. They provide more information about community composition than simply richness, as they also take the relative abundances of different species into account.

The Shannon's diversity index $\left(\mathrm{H}^{\prime}\right)$ allows to compare the potential dominances:

$$
\begin{aligned}
& \mathrm{H}^{\prime}=-\Sigma((\mathrm{Ni} / \mathrm{N}) * \log 2(\mathrm{Ni} / \mathrm{N})) \\
& \mathrm{Ni} \text { : number of individuals by species } \\
& \mathrm{N} \text { : total number of individuals }
\end{aligned}
$$

The index $\mathrm{H}^{\prime}$ can range from 0 to $1 . \mathrm{H}^{\prime}=0$ if all individuals of the community belong to a single species. $\mathrm{H}^{\prime}$ is minimal when one species dominates. The index is maximal when all individuals are distributed equally over all species (Frontier, 1983), i.e when species have similar abundances.

The Simpson's diversity index (D) permits to measure the probability that two randomly selected individuals belong to the same species:

$$
\mathrm{D}=\Sigma \mathrm{Ni}(\mathrm{Ni}-1) / \mathrm{N}(\mathrm{N}-1)
$$

$\mathrm{Ni}$ : number of individuals by species

$\mathrm{N}$ : total number of individuals

A value of 0 indicates a maximal diversity; a value of 1 indicates a minimal diversity.

\section{ARCHAEOLOGICAL CONTEXT OF ELISEEVICHI 1}

The site of Eliseevichi 1 was discovered in 1930 by K.M. Polikarpovich on a promontory of the Sudost' river, a triburaty of the Desna river. It was excavated by him (in 1935, 19361946 and 1948), V.D. Budko (in 1963 and 1965) and L.V. Grekhova (in 1970, 1972, 1974, 1976, 1978, 1980 and 1986). A monography was published by A.A.Velichko et al. (1997). G.A. Khlopachev made new investigations at the site in 2010-2011 and 2013, in collaboration with the geologist Yu. N. Gribchenko, the palynologist T.A. Sapelko, the paleontologist M.V. Sablin and the geochemist M.A. Kul'kova, to better define the geology and chronostratigraphy of the site (Khlopachev et al., 2013) (Figure 3).

The geological study was made by V.I. Gromov (1948), K.M. Polikarpovich (1968), and A.A. Velichko (1961). A new stratigraphical profile was studies in 2011 by Yu.N. Gribchenko (Khlopachev et al. 2013). One cultural layer was found about 1.70 meters deep in light gray sandy clay sediments. The site has delivered 274862 lithic artefacts in total, including 35,153 ones discovered in 1935 and 10,912 in 1936. The lithic material studied by K.M. Polikarpovich (1968), and L.V. Grekhova (1987), include prismatic nuclei. Tools are composed of burins, backed bladelets (simple ones and bladelets with semiabrupt inverse retouch), retouched backed microliths by abrasion, scrapers, perçoirs and points. The tools were made on blade, especially burins. The tool equipment is typologically not very diverse and is dominated by burins and backed bladelets. There are very few scrapers (Table 3; Figure 4). This lithic assemblage is attributed to the Epigravettian techno-complex. According to D.Yu. Nuzhnyi (2006), the lithic material from Eliseevichi 1 is unique in its composition and typology. For other researchers this industry is related to traditions from Central Europe (Desbrosse and Kozlowski, 1988). Flint may have been imported from the Khotylevo region (Velichko et al., 1997), in Cretaceous deposits $40 \mathrm{~km}$ north of Eliseevichi and processed on the site to make microlithic projectile insets and tools.

Radiocarbon dating provided results between 12630 and 33000 BP. However the majority of dates correlated with stratigraphy and cultural artifacts belong to the final phase of the second part of the Upper Pleniglacial, about 14000 BP.

\section{OTHER ARCHAEOLOGICAL SITES OF THE DESNA RIVER VALLEY}

All the sites are localized on the right bank of the Desna. They are dated to the Oldest Dryas (Dryas I) around 15 - 14000 BP (Svezhentsev and Popov, 1993; Abramova et al., 2001; Dolukhanov et al., 2001; Khlopachev, 2014) and attributed to the Epigravettian technocomplex (Table 3; Table 4). 
The Eliseevichi 2 site, located 20-50 meters from Eliseevichi 1, was discovered in 1979 during construction work. This work is at the origin of the disturbance of a part of the site. The cultural layer provided an accumulation of mammoth bones and several osseous artefacts (Grekhova, 1981). This site contains low information to be taken in account here.

The Timonovka 1 site, discovered in 1927, was investigated by M.V. Voevodski and V.A. Gorodtsov between 1928 and 1933 (Voevodski, 1929; Gorodtsov, 1935). The cultural layer was localized in a humified loam associated with loess at the top. According to the authors, hearths were present. They also conclude to the presence of mammoth bone dwelling structures and storage pits. The lithic industry is abundant: more than 100000 artefacts, 6023 tools). The most characteristic category of tools is represented by various backed microliths and other lithic points, connected with projectile weapons (Gavrilov, 1994).

The Timonovka 2 site, discovered in 1965, was excavated from 1965 to 1968 by L.V. Grekhova. The cultural remains were found in humic loam. It presents hearths and pits with mammoth bones.

Both Timonovka sites showed serious cryogenic destructions (Velichko et al., 1977).

The Suponevo site was excavated by P.P. Efimenko and B.S. Zhukov. The material was not published neither analyzed. I.G. Shovkoplias worked with the notes (1950). Cultural remains layed in colluvial laminated loam and sandy loam. Several hearts were present. According to I.G. Shovkoplias mammoth remains may correspond to the remnants of mammoth bone dwellings and storage pits. However this hypothesis remains unresolved.

The Yudinovo site was discovered in 1934 and investigated by K.M. Polikarpovich in 1947 and 1961 (Polikarpovich, 1968), then by V.D. Bud'ko in 1962, 1964, 1966, and 1967. From 1995, the fieldwork was led by G.V. Grigor'eva and since 2004 it has been led by G.A. Khlopachev (Khlopachev et al., 2006; Germonpre et al., 2008). It is characterized by the presence of mammoth bone dwellings, storage pits and hearths.

The Bugorok site (also called Pushkari 9) was discovered in 1940 by M.V. Voevodski. The excavations I-III were led by him and M.D. Gvozdover (Gvozdover, 1947; Voevodski, 1952a). Between 1997 and 2009, the excavations IV-V-VI were directed by G.A. Khlopachev (2014). The lithic industry is represented by nucleus, scrapers, burins, blades, microblades made of local flint. The new investigations allowed to better understand the stratigraphical situation of the site. The upper layer is composed of two horizons. The lower horizon is dated to around $15000 \mathrm{BP}$ (Klopachev and Kulkova, 2007; Gribchenko and Kurenkova, 2014). L.V. Grekhova (1970) and G.A. Klopachev (2014) concluded that the industries of Bugorok, Chulatovo 1, Chulatovo 2, Suponevo, Timonovka 1 and 2, and Yudinovo are closely related.

The Buzhenka 2 site was discovered in 2003. It was excavated until 2007 by D.V. Stupak (2011). The archaeological remains of upper layer were in loess. The lithic industry contains mainly microliths, then burins and scrapers, related to the Mezhyrichian (Stupak, 2011).

The Chulatovo 1 site, discovered in 1935, was excavated by I.G. Pidoplichko in 1935 and M.V. Voedvoski in 1937. Cultural remains were discovered in a chalk quarry and the site was subsequently destroyed. Several ashes areas which could be hearths were described (Boriskovski, 1953).

The Chulatovo 2 site, discovered in 1935, was excavated by I.G. Pidoplichko and A.M. Galich in 1936, and by M.V.Voevodski in 1937-38. The cultural layer was in loess. Several hearths and storage pits were identified (Boriskovski, 1953).

The Mezin site was discovered in 1908 by F.K. Volkov, and was excavated during many decades by different archeologists such as P.P. Efimenko, M.V. Voevodski, and I.G. Shovkoplias. Cultural material was in colluvial loess deposits laminated with sandy and clayey layers. The microliths include microgravettian (Nuzhnyi, 2006). They present some similarities with Suponevo collection. Several mammoth bone dwelling, pits and hearths were found.

Several archaeological specimens show long distance travels of populations or more probably exchange networks. Amber objects were present in Chulatovo 2 and Mezin. Chulatovo 2 amber comes from 260 kilometers away. In Mezin it comes from 220 kilometers away (Soffer, 1985b).

The Eliseevichi 1, Chulatovo 2, Timonovka 1, Yudinovo and Mezin sites have yielded shells. The Eliseevichi 1 fossils of Annelids come from the Black Sea, 600 kilometers away. Shells excavated in Eliseevichi 1, Timonovka 1 and Yudinovo come from the Black Sea between $600 \mathrm{~km}$ and $800 \mathrm{~km}$ away (Soffer, 1985b; Germonpré, 2008). The Mezin site presents fossil marine shells coming from Podolia, 500 kilometers away (lakovleva, 2005).

So the sites of Timonovka 1 and 2, Yudinovo, Bugorok and Chulatovo are characterized by a high representation of mammoth remains, an abundance of burins, end-scrapers, microliths then blades with various truncations (Nuzhnyi, 2006).

In Mezin, contrary to the larger part of East Epigravettian industries, the blade processing was based mainly on the use of prismatic and 
sub-pyramidal cores with one striking platform (Nuzhnyi, 2006).

The cultural connection of Mezinian industry with Yudinovian ones is also not yet clear.

The Eliseevichi 1 site contains quite specific lithic industry (including backed microliths processed by a characteristic abrasive retouch) and portable art objects, making this site a unique assemblage.

Except Chulatovo 1, which could be a temporary camp, the other sites are interpreted as base camps.

Table 1. Informations about archaeological sites of the Desna valley.

\begin{tabular}{|l|l|l|l|l|l|}
\hline \multicolumn{1}{|c|}{ Sites } & \multicolumn{3}{c|}{ Position of sites } & \multicolumn{1}{c|}{ Orientation } & \multicolumn{1}{c|}{ Preservation } \\
\hline Eliseevichi 1 & plateau (promontory) & Sudost' & right bank (north) & East & well, periglacial phenomena \\
\hline Timonovka 1 & plateau (promontory) & Desna & right bank (west) & South-East & disturbed \\
\hline Timonovka 2 & plateau (promontory) & Desna & right bank (west) & South-East & periglacial phenomena \\
\hline Suponevo & plateau (promontory) & Desna & right bank (west) & East & well \\
\hline Yudinovo & plateau (promontory) & Sudost' & right bank (north) & South-East & well \\
\hline Chulatovo 1 & plateau (promontory) & Desna & right bank (west) & South-East & erosion, solifluction \\
\hline Chulatovo 2 & plateau (promontory) & Desna & right bank (west) & South & erosion \\
\hline Mezin & plateau (promontory) & Desna & right bank (north) & South-West & well \\
\hline Bugorok & plateau (promontory) & Desna & right bank (west) & South & well \\
\hline
\end{tabular}

Table 2. Informations about archaeological remains conditions (faunal remains without micromammals, avifauna and ichtyofauna).

\begin{tabular}{|c|c|c|c|c|c|c|c|c|c|c|}
\hline \multirow[b]{2}{*}{ Sites } & \multirow{2}{*}{$\begin{array}{l}\text { Surface } \\
\qquad\left(\mathbf{m}^{2}\right)\end{array}$} & \multirow{2}{*}{$\begin{array}{c}\text { Thickness }(\mathrm{cm}) \text { of } \\
\text { the cultural layer } \\
\text { [mean value] }\end{array}$} & \multicolumn{3}{|c|}{ Lithic remains } & \multicolumn{2}{|c|}{ Faunal remains } & \multirow[b]{2}{*}{ Ocher } & \multirow[b]{2}{*}{ Hearths } & \multirow{2}{*}{$\begin{array}{c}\text { Mammoth } \\
\text { bone } \\
\text { dwellings }\end{array}$} \\
\hline & & & NR & Tools & $\begin{array}{c}\text { Local raw } \\
\text { material }\end{array}$ & NR & MNIC & & & \\
\hline Eliseevichi 1 & 623 & $10-12$ [11] & 80000 & 4000 & no & 28754 & 405 & yes & no & yes \\
\hline Timonovka 1 & 1178 & $7-15$ [11] & 110095 & 10447 & I & 1 & 24 & yes & \multirow{7}{*}{ yes } & $?$ \\
\hline Timonovka 2 & 163 & 5-15 [10] & 13932 & 632 & I & 121 & 23 & yes & & $?$ \\
\hline Suponevo & 200 & 30 & 30000 & 1 & I & 414 & 16 & yes & & yes \\
\hline Yudinovo & 500 & $20-40$ [30] & 12500 & I & no & 506 & 102 & yes & & yes \\
\hline Chulatovo 1 & 390 & 25 & 1200 & 42 & I & 1137 & 37 & no & & no \\
\hline Chulatovo 2 & 1000 & $2-5[3]$ & 13387 & 535 & yes & I & 124 & yes & & no \\
\hline Mezin & 1200 & $10-15[12]$ & 113238 & 4429 & yes & 8260 & 486 & yes & & yes \\
\hline
\end{tabular}

\section{ZOOARCHAEOLOGICAL RESULTS OF ELISEEVICHI 1 - 1935-36}

\section{Quantification}

The three main species of Eliseevichi 1-193536 are polar fox (Alopex lagopus rossicus), which is predominant, wolf (Canis lupus) and woolly mammoth (Mammuthus primigenius) (Table 1). We observed that few bones are fragmented, mainly ivory and long bones of canids.

Fox was identified as a subspecies of polar fox Alopex lagopus rossicus (Kuzmina and Sablin, 1993; Sablin, 1994). It is also described in Yudinovo and Kostienki (Baryshnikov, 2006).
From the 33 mammoth skulls previously mentioned (Polikarpovich, 1968), three of them are still existing. The available data about the missing skulls (we do not have data about the number of teeth) are combined with our descriptions. Other horse, bear and hare bones, previously indicated, are also lacking in the studied material.

Two canid skulls (MAE 447/5298; ZIN 23781/24) were previously identified as being those of dogs (Polikarpovich, 1968; Velichko et al., 1997). New studies by M.V. Sablin and G.A. Khlopachev (2001; 2002) and Germonpré et al. (2015) confirm their presence. 
Table 3. Count of faunal remains, Eliseevichi 1 - 1935-36.

\begin{tabular}{|c|c|c|c|}
\hline Species & NRt & MNE & MNIc \\
\hline Mammuthus primigenius & $698\left(731^{*}\right)$ & $43\left(76^{*}\right)$ & $5\left(36^{*}\right)$ \\
\hline Canis lupus familiaris & 14 & 14 & 2 \\
\hline Canis lupus & 329 & 279 & 10 \\
\hline Alopex lagopus rossicus & 6281 & 5181 & 131 \\
\hline Ursus arctos & $19\left(23^{*}\right)$ & 18 & $3(* 5)$ \\
\hline Rangifer tarandus & 3 & 2 & 1 \\
\hline *Equus sp. & $(1 *)$ & $(1 *)$ & $(1 *)$ \\
\hline L. timidus & $(1 *)$ & $(1 *)$ & $(1 *)$ \\
\hline Total of identified specimens & 7344 (7383*) & $5537(5572 *)$ & $152\left(187^{*}\right)$ \\
\hline Carnivore (teeth) & 8 & 4 & \\
\hline Large sized mammal & 29 & & \\
\hline Large sized/ medium sized mammal & 16 & 5 & \\
\hline Medium sized mammal & 23 & 1 & \\
\hline Total & 7420 (7459*) & $5547(5582 *)$ & $152\left(187^{*}\right)$ \\
\hline
\end{tabular}

With Polikarpovich data*

\section{Modalities of taphonomical preservation}

According to our taphonomical analyses, the bones of Eliseevichi 1 (1935-1936), are very well preserved (Figure 4; Figure 5). They were buried quickly and deeply under a dry and cold climate (Figure 5). Some bones of foxes were still in anatomical connexion, so they were fresh carcasses.

Mammoth bones show a different stage of preservation with much deterioration caused by percolating and runoff waters. K.M. Polikarpovich (1968) mentioned that they were mainly situated in small depressions (pits) (1968). This location may explain the rather dark color of mammoth bones, with phenomena of concentration and stagnation of metal elements.

\section{Skeletal preservation}

Concerning the skeletal preservation of mammoth, all anatomical parts are represented especially from juveniles. The representation of teeth is predominant in particular tusks (Table 4 ; Figure 6). So on the one hand we can suggest that juvenile mammoths died near this place; on the other hand, tusks of adult s.l. could have been intentionally stored.

Table 4. Detailed count of main species from Eliseevichi 1 - 1935-36.

\begin{tabular}{|c|c|c|c|c|c|c|c|c|c|c|}
\hline & & \multicolumn{3}{|c|}{ M.primigenius } & \multicolumn{3}{|c|}{ A. lagopus rossicus } & \multicolumn{3}{|c|}{ C. Iupus } \\
\hline & & NR & MNE & MNIc: & NR & MNE & MNIc: & NR & MNE & MNIC: \\
\hline \multicolumn{2}{|l|}{ TOTAL } & 698 & 43 & 5 & 6281 & 5181 & 131 & 329 & 279 & 10 \\
\hline \multicolumn{2}{|l|}{ cranial skeleton } & 481 & 11 & & 1274 & 985 & & 110 & 83 & \\
\hline \multicolumn{2}{|l|}{ postcranial skeleton } & 152 & 31 & & 4589 & 4106 & & 203 & 184 & \\
\hline & axial skeleton & 144 & 23 & & 1151 & 1015 & & 16 & 16 & \\
\hline & anterior upper parts & 2 & 2 & & 721 & 513 & & 53 & 35 & \\
\hline & $\begin{array}{l}\text { anterior basipod }+ \\
\text { metapodial }\end{array}$ & 0 & 0 & & 594 & 593 & & 33 & 33 & \\
\hline & posterior upper parts & 1 & 1 & & 401 & 270 & & 10 & 9 & \\
\hline & $\begin{array}{l}\text { posterior basipod }+ \\
\text { metapodial }\end{array}$ & 1 & 1 & & 951 & 944 & & 39 & 39 & \\
\hline & acropod & 4 & 4 & & 771 & 771 & & 52 & 52 & \\
\hline \multicolumn{2}{|l|}{ not totally identified } & 64 & 1 & & 418 & 90 & & 16 & 12 & \\
\hline
\end{tabular}

In terms of skeletal preservation by anatomical parts, the Canids of Eliseevichi 1 cranial skeleton (\%MAU: 19.77\%; Ps: 16\%) and postcranial skeleton (\%MAU: 14\%; Ps: 11.3\%) exhibit a similar representation (Tableau 1; Figure 7). All anatomical parts are represented. The upper forelimb is the 
best preserved part, while the axial, acropod and sesamoids are rare (Figure 6). So the carcasses of Canids have been bringing back almost complete to the site.

Anthropogenic exploitation of the main species

Concerning mammoth we observed butchering cutmarks on juvenile and adult bones, relied with defleshing for food. Many pieces of ivory show grooving marks related with a chaine opératoire and sometimes without being attached to a well-defined working process. A part of them are "finished products" (Figure 8). So the mammoth has been heavily used in the site Eliseevichi 1 .

The bones of Canids present butchering cutmarks related to skinning, disarticulation and defleshing and fracturation marks. Then, a part of long bones and several metapodials were grooved and sawn (Figure 9). So on the hand these carcasses were exploited for fur, and on the other hand bones were exploited as industrial supports. It may be a support with volume used as needle cases (ethnographically known but it would require traceological analyzes), described in particular in Gagarino (Zamiatnine, 1935), or offcuts products worked for making ornaments objects.

Main conclusions about faunal exploitation in Eliseevichi 1 (1935-36)

According to the study we highlighted butchering activities on mammoths, probably related with their consumption by human groups.
The bone and ivory in particular has been heavily exploited for making various objects that can be linked to industrial activities (needles, splinters polished) and artistic (decorated plates, female statuette). This practice reflects the advance management of the raw material, and specialized technical know-how. The fox and the wolf were exploited for fur. The presence of ocher, ashy areas of lithic raw splinters of polished bones could be related to the operating chain of treatment of skin. Providing as many animals requires a very good organization in necessary prior trapping activities. The Eliseevichi 1 site could therefore have two main functions, the fur and manufacturing of tools and ornaments pieces in bones and ivory. According to the possibility of slaughter of juvenile mammoths to the season of birth and the optimal season for exploitation of fur of carnivores, the site could have been occupied several times during the summer/ autumn and winter. The Eliseevichi 1 site remains relatively difficult to position in the regional culture. It would be interesting to know what it is exactly the status of animals and particularly if bones of mammoth were used as building material to clarify whether this is a specialized habitat in regional culture or if it is strictly a site workshops.

Comparison of the excavations 1935-36 with the whole site of Eliseevichi 1

Comparing Eliseevichi 1 - 1935-36 to the total of the site, M. putorius and $A$. alces are absent in the first one, but the different species have a similar representation (Table 5; Figure 10).

Table 5. Count of faunal remains, Eliseevichi 1 (Polikarpovich, 1968; Velichko et al., 1997; Soffer, 1985a).

\begin{tabular}{|c|c|c|c|c|c|c|c|c|c|c|}
\hline \multirow{2}{*}{ Species } & \multicolumn{2}{|c|}{1935} & \multicolumn{2}{|c|}{1936} & \multicolumn{2}{|c|}{ 1930-1940 } & \multicolumn{2}{|c|}{ 1970-1978 } & \multicolumn{2}{|c|}{ TOTAL } \\
\hline & NR & MNIC & NR & MNIC & NR & MNIC & NR & MNIC & NR & MNIC \\
\hline M. primigenius & \multicolumn{4}{|c|}{ MNIC 30} & several thousands & at least 60 & $\sim 700$ & $\sim 24$ & $>12187$ & 60 \\
\hline Equus sp. & I & / & 1 & 1 & 1 & 1 & / & / & 1 & 1 \\
\hline R. tarandus & / & / & I & / & 1 & 1 & 2 & 1 & 3 & 1 \\
\hline A. alces & I & I & I & 1 & 1 & 1 & 1 & 1 & 1 & 1 \\
\hline C. lupus & 80 & 4 & 116 & 4 & 903 & 36 & 123 & 6 & \multirow[t]{2}{*}{1059} & \multirow[t]{2}{*}{36} \\
\hline C. Iupus familiaris & 1 & 1 & 2 & 1 & / & I & I & I & & \\
\hline A. lagopus & 1087 & 51 & 2101 & 51 & 14564 & 287 & 410 & 14 & \multirow[t]{3}{*}{15392} & \multirow[t]{3}{*}{291} \\
\hline V. corsac & 5 & 3 & 1 & 1 & 6 & 4 & 5 & 1 & & \\
\hline Vulpinae & 1 & 1 & 1 & 1 & 2 & 2 & 1 & 1 & & \\
\hline U. arctos & 12 & 3 & 11 & 5 & 89 & 10 & 1 & 1 & 96 & 10 \\
\hline L. timidus & 1 & 1 & 1 & 1 & 3 & 2 & 1 & 1 & 4 & 2 \\
\hline L.obensis & 6 & 2 & 1 & 1 & 17 & 5 & 1 & 1 & 17 & 5 \\
\hline Cricetus sp. & 8 & 1 & 1 & 1 & 13 & 3 & 1 & 1 & 13 & 3 \\
\hline C. corax & 1 & 1 & 1 & 1 & 1 & 1 & 1 & I & 1 & 1 \\
\hline B. bubo & 1 & 1 & 1 & 1 & 1 & 1 & 1 & 1 & 1 & 1 \\
\hline L. lagopus & 1 & 1 & 1 & 1 & 1 & 1 & 1 & I & 1 & 1 \\
\hline M. putorius & 1 & 1 & I & 1 & 5 & 2 & 1 & 1 & 6 & 2 \\
\hline G. gulo & 1 & 1 & 1 & 1 & 1 & 1 & 1 & 1 & 5 & 1 \\
\hline Dicrostonyx sp. & 1 & 1 & I & 1 & 1 & I & 1 & I & 7 & I \\
\hline M. gregalis & I & I & I & 1 & 1 & 1 & 1 & 1 & 4 & I \\
\hline Cyprinidae sp. & 1 & 1 & I & 1 & 1 & 1 & 1 & 1 & 27 & 7 \\
\hline & & & & & & & & & $>28825$ & $>423$ \\
\hline
\end{tabular}




\section{COMPARATIVE ANALYZES OF THE DESNA ARCHAEOLOGICAL SITES}

\section{Paleoecology}

Vegetation

According to the palinological study of Eliseevichi 1, species are varied, with a preponderance of taxa related to an open and arid environment under a cold climate, particularly in sandy loam sedimentary context (Betula fruticans, B. nana, B. pendula, B. pubescens, Botrychium boreale, Cystopteris sudetica, Corispermum hyssopifolium, Eurotia ceratoides, Fagopyrum sp.). Some species are more typical of a tree cover along rivers (Alnus incana, Lythrum salicaria, Plantago sp.) (Zelikson, In Velichko et al. 1997 ; Sapelko, In Khlopachev et al., 2013).

Timonovka 2 is dominated by Gramineae, Polygonaceae, Umbelliferae, Chenopodiaceae and Compositea (Velichko et al., 1981).

Concerning Yudinovo the palynological study presents wooded area (artic-boreal trees and shrubs) and meadow plants (L. Clavatum, L. selago, $P$. aquilinum) close to the site. It reveals relatively humid conditions (Buynevich et al., 2011).

The Bugorok site revealed the presence of grasses, and in particular of Poaceae (Cichoriaceae sp., Rubiaceae sp., Polygonaceae sp., Brassicaceae sp., Fabaceae sp., Asteraceae sp.) (Sapelko, 2014). The concerned cultural horizon is correlated with the steppe-tundra communities.

So these sites are related to a steppe environment with the presence of well developed riparian forests.

\section{Fauna}

The faunal remains of Bugorok are poorly preserved, composed of fragmented bones, teeth and ivory (Gvozdover, 1947; Voevodski, 1940). M.V. Sablin (2002) identified the faunal remains of the excavation $\mathrm{VI}$ as $M$. primigenius (woolly mammoth), O. moschatus (musk ox) and A. lagopus (Arctic fox),

The faunal remains of Buzhenka 2, upper layer are represented by fragments of bones of M. primigenius, C. lupus, Vulpinae, Ursus sp. and R. tarandus (Péan, In: Stupak, 2011).

There are few possibilities of comparisons from these both sites, but fauna is typical of an open landscape under dry and cold environment.

Timonovka 1 is dominated by mammoth, Timonovka 2 by mammoth and Vulpinae. Suponevo presents mainly mammoth then large canids. Yudinovo and Chulatovo 1 are dominated by mammoth, then Vulpinae. Chulatovo 2 is dominated by marmot then Lepus sp. and reindeer, rhinoceros, Vulpinae and mammoth. Mezin is dominated by mammoth, Canids and horse (Figure 11). Fauna of the sites of the Desna valley present all the characteristics of an open landscape. The presence of teeth of suidae in Mezin is questionable. Indeed this species is more adapted to more humid and closed landscape. It is possible that just only teeth were gathered in another region or that they were exchanged between human groups.

We can reconstruct the paleoecology, taking also into account the microfauna, ichtyofauna and avifauna (Figure 12). Of course, in archeological sites, the diversity could be biased by anthropogenic activities. Taking in account the taxonomy, Rodents are well represented in all sites, particularly in Chulatovo 2. Many carnivorous are present followed by artiodactyls and perissodactyls, then ichtyofauna and avifauna. There are few insectivores. In terms of weight we observed many small-sized terrestrial mammals and large-sized terrestrial mammals, whose runner mammals, with also presence of aquatic and burrower species. The dietary adaptation is dominated by hypsodont herbivorous and carnivores, then brachyodont herbivorous and omnivorous.

The sites of the Desna valley present all the characteristics of an open landscape, with abundant grazing areas, with the proximity of water sources, riverbanks and arboreal spaces.

The cenograms are workable on four sites (Figure 13). They are related to an open landscape, more arid in Eliseevichi 1 and Chulatovo 2. Yudinovo seems to be more humid than the other sites.

We processed to the evaluation of diversity indexes taking in account the mammals including Lepus sp.. From Shannon's index, Eliseevichi 1 and Timonovka 1 and 2 are dominated by few species (Figure 14). From Simpson's index, Suponevo and Chulatovo 1 and 2 are highly diversified, whereas Eliseevichi 1 is the least diversified one (Figure 15).

Considering the impact of erosion and periglacial phenomena in Chulatovo 1 and 2 and Timonovka 1 and 2, the representation of the faunal remains could be biased, by dispersion or intrusion of bones. It is also possible that Chulatovo was characterized by an anthropogenic diversified selection of prey. In comparison, Eliseevichi 1 is highly specialized on few species. These observations have to be linked with human activities.

\section{Lithic representation}

Relating the number of lithic remains and tools, all the sites exhibit a regular ratio, except Timonovka 1 which contains many tools (Figure 16).

Comparing the number of lithic remains by $\mathrm{m}^{3}$, we can observe that Elissevichi 1 is the densest site. Tools are more densily present in Timonovka 1 , 
then Timonovka 2 and Eliseevichi 1 than in the other sites (Figure 17).

So the site of Eliseevichi 1 is represented by a ratio of lithic remains and tools which is the same in all the sites. However the remains density is high.

\section{Density of faunal remains}

Concerning the density of faunal individuals, Eliseevichi 1 is the most important site, followed by Mezin (Figure 18).

If we compare the main species fox, wolf and mammoth, fox is characterized by a high density in termes of individuals in Eliseevichi 1 . Wolf is well represented in Eliseevichi 1, then in Mezin. Concerning mammoth it is well represented in Eliseevichi 1, Mezin, Timonovka 2, then Chulatovo 2 and Yudinovo (Figure 19).

\section{EXPLOITATION OF IVORY AND BONE RAW MATERIAL}

Technical processes related to the boneous industry in general, including the ivory, require a very good knowledge of the material for a relatively long chaîne opératoire (Semenov, 1957). So the management should be well anticipated by specialists. Ivory was exploited in Eliseevichi 1, Timonovka 1, Suponevo, Yudinovo and Mezin. They can obtain support with volume as cylindridal fragments of tusks, or flat supports produced from transverse flakes (Klopatchev, 2001). Both processes related technologies of tusk-knapping were applied in all sites (Klopatchev, 2001; Lázničková-Galetová, 2012) (Figure 15). Compared to other sites, Eliseevichi 1 contains mainly flat supports. The transversal break-up of wide flakes was used. Longitudinal flakes were obtained on inclined negatives of the tusk edges. The ivory industry of Eliseevichi 1 does not have direct analogies with the known industries in Eastern Europe (Khlopachev, 2006).

Objects made from animal organic materials were found (Figure 21).

Eliseevichi 1 presents more than 200 pieces, including awls, needles, ivory plates, a female ivory statuette and a limestone marl mammoth. Some ivory plates were decorated with fish scales called "churingas" (Polikarpovich, 1968).

Timonovka 1 presents fragments of ivory bracelets with linear decoration, ivory projectile points, fragments of ivory needles and lissoirs.

Suponevo contains several worked or decorated ivory pieces, as pearls or plates.

In Yudinovo, there are ivory and bone, points, awls, needles, pendants and plates and ivory decorated rods. There is a bird made from reindeer antler.

In Mezin animal bones were used to make ivory points, needles, awls, hammers from antler, lissoirs, bâtons percés, female or phallic figures, animal figures, pendants and bracelets, often covered by geometric meanders (Shovkoplias, 1965). Pendants in ivory drop-like form with hole and with double swellings with transversal trough are typical of this site.

Long bones of foxes were sawn and incised in Eliseevichi 1, Timonovka 1, Suponevo and Mezin (Figure 22). Some of them were interpreted as awls. In Eliseevichi 1 the working bones of wolf is quite exceptional in the area.

\section{SEASONALITY}

From the faunal remains we propose seasons of settlements (Figure 23).

Concerning the seasonality in Eliseevichi 1, interpretations are made by us from canids and mammoths.

The best season for human group to exploit canids is in winter. Indeed during the automn they moult, and during the winter their fur have a large isothermal capacity. So it is the best period for optimal acquisition of fur by human groups. Moreover, the reproduction period of foxes and wolves is January-February. They deposit many faeces and urine which are identifiable for tracking. Concerning foxes, during the winter, females settle burrows; males travel several kilometers to find a female. At this time they are not very aware of their environment. They are vulnerable and easier to trap. Moreover, as they mark the territory, other males will inevitably return to the same place, suitable for trapping (Schemnitz, 2005). So we can propose that canids of Eliseevichi 1 were killed in winter.

Concerning mammoths, we identified three juveniles. One is represented by a milk tusk and died around 1-3 months old. A mandible has a left $\mathrm{dp}_{3}$ and a right $\mathrm{dp}_{2}$. According to the stages of eruption and wear (Laws, 1966), it exhibits a stage III (an individual younger than one year-old/one and half year. An isolated pp3 (stage V) belongs to an individual of around three years-old. Within living elephant populations, births take place at random times. However it is plausible, given the harsh climate during glacial periods, that birth of mammoth favored calves survival in warm season. Works on juvenile mammoth carcasses found in Siberian permafrost show that births took place in spring (Rountrey et al., 2012). So we can propose that mammoths of Eliseevichi 1 were hunted between July and October.

If we take into account ptarmigan, this animal migrates to the south between November and March. So the human groups of Eliseevichi 1 could have settled the site several times at different seasons. 
In Yudinovo, mammoth could have been hunted in winter (Germonpré et al., 2008; Sablin, 2014). Canids could have been acquired in winter too. Unless snowy owl could have been introduced intrusively in the layer, we can consider that this species migrate to the South between November and December. This site would have been settled in winter.

In Mezin ptarmigan is well represented. It could have not been acquired in winter. Marmots could have been killed in summer when they are fatter. The wheatear could have been intrusively introduced, but if it has been killed it was present from spring to automn. Reindeers were hunted in winter (Klein, 1973). Moreover several pits have been dug in the site. According to J.-F. Hoffecker (2002) these kinds of pits could have not been dug during the cold season. So this site could have been occupied during different seasons.

Precisions about individual age of animals are not available, neither well represented migrant species, that would help us to propose seasonal settlements. O. Soffer (1985a) proposed from reindeers that Timonovka 1 and 2 were occupied in cold season and that Suponevo has been occupied in cold and warm seasons. In Chulatovo 1 and 2 it is difficult to estimate.

\section{FUNCTIONAL INTERPRETATION OF ELISEEVICHI 1}

Contrary to the other sites, Eliseevichi 1 is more specialized, with almost none species acquired opportunistically. Furthermore, in Timonovka 1 the high representation of flint remains and the specialized exploitation of fauna are questionable too.

In Eliseevichi 1, it is possible that human groups have mainly exploited mammoth or they have taken food with them. As in other sites they practiced leatherwork and ivory work. However contrary to the other base camps with more varied species and activities, it seems to be the main activities in Eliseevichi 1. So we doubt of the interpretation of Eliseevichi 1 as a base camp. Thus we question also the interpretation of the pits with mammoth bones as house structures. Indeed pits around two large meters were excavated with mammoth bone remains. As we can see these remains are essentially cranial bones (skulls, tusks, mandibles) (Figure 24). They were interpreted as dwelling structures. It is possible that these pits were storage pits (Figure 24). An entire carcass of elephant decomposes in sixteen days in the presence of scavengers and up to 53 days with minimal scavenger activity (Coe, 1978). From the known technics of elephants butchering (Haynes, 1991) the heads of elephant can be put in pits to decompose. Peoples can recover tusks in few days. Then they have to be soaked during three days to three months and eventually to be let in air dry for a month or two. They can be soaked again to be worked. Off course the present african climate is different from the Upper Palaeolithic periglacial european steppe. In semiarid shrubsteppe ecosystem the decomposition of a complete carcass of large-sized mammals as red deer can take more than one year (Parmenter and MacMahon, 2009).

In Eliseevichi 1 we know it is not sub-fossile ivory. It is possible that the fresh heads with tusks or collected on recent carcasses, have been put into pits used for natural maceration of the connective tissue in the tusk alveoli (Basilyan et al., 2011; Pitulko et al., 2015). Then ivory was recovered to be worked later. Probably fresh hunted mammoth or dried carcasses were near the site. This involves management over several years.

\section{CONCLUSIONS}

The archaeological site of Eliseevichi 1 shows the variety of the activities of human groups in the end of the second half of the upper Pleniglacial. We applied zooarchaeological methods about the faunal remains of the excavations 1935-36 to better define the modalities of exploitation of fauna. The two main species are mammoth and fox. All these remains are very well preserved, with wellpreserved surfaces and elements in anatomical connection, indicating a good preservation of the site. However mammoth remains are more affected by weathering and percolation water effects. According to the study, we highlighted butchery marks on juvenile mammoths, probably related with their consumption by human groups. Mammoth bones and ivory of adults have been exploited for the manufacture of various objects that can be linked to industrial and artistic activities. The remains of canids in particular foxes, are numerous. The skeletal preservation shows that complete carcasses have been bringing back on the site. The anthropogenic stigmata permit to demonstrate exploitation of fur. The long bones and metapodials were incised and sawn, maybe to make ornaments or as needle cases. So this site is characterized by different activities, lithic exploitation, mammoth exploitation (maybe hunting and/or gathering) for food and ivory and carnivore exploitation, during the summer and the winter.

This site was interpreted as a base camp with remains of mammoth dwellings. However the faunal spectrum is very restricted and we have mainly mammoth skulls and tusks for adults. So to better understand environmental conditions and anthropogenic activities, we compared our analyses with data from the complete site of 
Eliseevichi 1 and contemporaneous sites of the Desna river valley.

There are all localized on the right bank of the Desna river. Canids and mammoth are generally dominant within the archeological assemblages. From environmental data and faunal spectrum they are all characterized by an open landscape, with abundant grazing areas, with the proximity of water sources, riverbanks and arboreal spaces. Yudinovo seems to be characterized by a wettest environment. From the faunal diversity, in base camps the faunal spectrum is quite diversified, with predominant species as mammoth in all sites, marmot in Chulatovo 2. However Eliseevichi 1 and Timonovka 1 are more specialized about few taxa, mammoth and canids.

These variations between sites can be related to more or less good preservation of the assemblages with possible intrusion or dispersion of bones. And they can be representative of anthropogenic selection of taxa.

All the sites show exploitation of ivory and carnivores arising of anthropogenic selections. It permits to show that fur acquisition is a main activities in these sites. But except in Eliseevichi 1 and Timonovka 1, all base camps are characterized by secondary exploitations of other animals. This could reflect the opportunistic acquisition of different mammals. So the interpretation of Eliseevichi 1 as base camp is questionable.

By taphonomical observations, skeletal representation and features on the site, related with mammoth remains, we think that the pits could have been used for natural maceration to collect tusks. So maybe this excavated area of Eliseevichi 1 is a workshop for flint, fur, bones and ivory. On the one hand it is possible that the base camp was located near. On the other hand it is possible that it was an important workshop within the territory.
These activities this require anticipating of resource management by alternance of activities during several years.

We want to see other faunal remains of the site, in particular the sector of 1948 excavated by V.D. Budko to precise the zooarchaeological study and particularly the large area of ashy and charcoal to precise the use of fire in the site.

\section{AKNOWLEDGEMENTS}

The zooarchaeological study was funded by the project «Utilisation du Mammouth: choix culturel ou adaptation environnementale?» (Vercoutère C. et Patou-Mathis M. (dir.), Dpt Préhistoire/ CNRS UMR 7194), Action Transversale du Muséum National d'Histoire Naturelle «Les dynamiques socio-écosystémiques : entre perturbations et résiliences environnementales et culturelles (ATM DS-E). New investigations on the site of Eliseevichi 1 were found by the Russian Foundation for Humanities (RFH N¹5-21-01001). The participation to the congress was funded by Equipe II - Comportements des Néandertaliens et des Hommes anatomiquement modernes replacés dans leur contexte paléoécologique HNHP Histoire Naturelle de I'Homme Préhistorique (UMR 7194).

The participation of ZIN RAS (state assignment № AAAA-A17-117022810195-3) to this research is acknowledged.

We thank D.Yu. Nuzhnyi, C. Vercoutère, L. Crépin and P. Noiret for their advices.

We thank P.S. Shidlovski and all organizers of the International scientific conference HUMAN \& LANDSCAPE : Geographical approach in the Prehistoric archaeology. The interaction between nature and society in Prehistoric Age, February 3-5, 2016, Kyiv. 


\section{REFERENCES}

Abramova, Z.A., Grigorieva, G.V. and Zaitseva, G.I. 2001. The age of Upper Paleolithic Sites in the Middle Dnieper River Basin of Eastern Europe. Radiocarbon 42, 1077-1084.

Abramova, Z.A., Grigorieva, G.V., 1997. Verchenepaleolititcheskoe Poselenie loudinovo (The Upper Paleolithic camp-site of loudinovo). Vol. 3, Saint -Petersbourg, Russian Academy of Sciences (in Russian).

Abramova Z.A., 1962, L'art paléolithique d'URSS . In : Corpus des sources archéologiques, A 4-3 (in Russian).

Andrews P., Lord J.M., Nesbit E.M. 1979. "Patterns of ecological diversity in fossil and modern mammalian faunas". Biological Journal of the Linnean Society 11: $177-205$.

Baryshnikov G., 2006. Late Pleistocene arctic fox (Alopex lagopus) from Crimea, Ukraine. Quaternary International, 142- 143: 208-217.

Basilyan A.E., M.A. Anisimov, P.A. Nikolskiy, and V.V. Pitulko. 2011. "Wooly Mammoth Mass Accumulation Next to the Paleolithic Yana RHS Site, Arctic Siberia: Its Geology, Age, and Relation to past Human Activity. Journal of Archaeological Science 38: 2461-74.

Boriskovski P.I., 1953. Paleolithic in Ukraine: Materials and researches about Archaeology of USSR, Academy of Sciences of USSR, Moscow-Leningrad.

Budko V.D., 1966. Verhnii paleolit severo-zapada Russkoi ravnini. In: Isaenko, V.F., Mitrofanov, A.G., Shitihov, G.V. (Eds), Drevnosti Byelorussii, pp. 6-21.

Budko, V.D., 1967. Novoye sooruzheniye is kostei mamonta v punkte Yudinovo I. Doklady Akadamii Nauk BSSR, 7: 651-653.

Budko, V.D., $\quad 1969 . \quad$ Yudinovskoye verhnepaleolitischeskoye poselenye. In: Tezisi dokladov k Konferentsii po arheologii Byelorussii, pp. 16-19.

Buynevich I.V., 2011. Geology and Geoarchaeology of the Black Sea Region: Beyond the Flood Hypothesis. Geological Society of America, Boulder.

Coe M (1978) The decomposition of elephant carcases in the Tsavo (East) National Park, Kenya. J Arid Environ 1:71-86.

Desbrosse, R., Kozlowski, J., 1988. Hommes et climats à l'âge des mammouths. Le Paléolithique supérieur d'Eurasie Centrale. Masson, Paris.

Djindjian, F., Kozlowski, J.K., Otte, M., 1999. Le Paléolithique supérieur en Europe. Armand Colin, Paris.

Dolukhanov P., Sokoloff D., Shukurov A., 2001. Radiocarbon Chronology of Upper Palaeolithic Sites in Eastern Europe at Improved Resolution. Journal of Archaeological Science, 28, 699-712.

Faure, M., Guérin, C., 1984. Sus strozzii et Sus scrofa, deux mammifères artiodactyles, marqueurs des paléoenvironments. Palaeogeography, Palaeoclimatology, Palaeoecology, 48, 215-228.

Gavrilov, K.N. 1994. Flint assemblages of Timonovka 1 site. In: Vestnik Moskovskogo Universiteta (Seriya 8, istoriya), 3: 63-76 (in Russian).

Germonpré, M., Sablin, M.V., Lázničková-Galetová, M., Després V., Stevens R.E., Stiller M., Hofreiter M., 2015. Palaeolithic dogs and Pleistocene wolves revisited: a reply to Morey (2014). Journal of Archaeological Science, 54, 210-216.

Germonpré, M., Sablin, M., Khlopachev, G.A., Grigorieva, G.V., 2008. Possible evidence of mammoth hunting during the Epigravettian at Yudinovo, Russian Plain. Journal of Anthropological Archaeology 27 (4): 475-492.

Gorodtsov, V.A., 1935. Timonovskaya Paleoliticheskaya stoyanka. Trudy Instituta Antropologii, Etnografii, I Arheologii 3: 1-50.

Gromov, V.I., 1948. Paleontologicheskoe i arkheologicheskoe obosvanie stratigrafii kontinental'nykh otlozhenii chetvertichnogo perioda na territorii SSSR, Moskva (in Russian).

Grekhova, L.V., 1987. Kremnevuj komplex stojanki Elisevichi// SA. N4, p. 123-139 (in Russian).

Grekhova, L.V., 1981. Raskopki Eliseevicheskoi stoyanki. In : Arheologicheskiye otkritiya 1980 goda, p.49.

Grekhova, L.V. 1971. The flint assemblage Timonovka 2 site and the similar assemblages of Desna river basin. In: Istoriya i kul'tyra Vostochnoj Evropy po arxeologicheskim dannym. Moscow, 3-22 (in Russian).

Grekhova, L.V., 1970. Timonovskiye stoyanki i ich mesto v Pozdem Paleolite Russkoi ravnini. Avtoreferat kandidatskoi dissertatsii na soiskaniye uchenoi stepeni kandidata istoricheskih nauk. Kafedra Arheologii, Istoricheskii Fakultet, Moskovskii Gosudarstvenii Universitet.

Gribchenko, Yu.N., Kurenkova, E.I., 2014. Paleogeographic features of the basic sites of aLate Paleolithic of Desna river basin (Khotylevo, Eliseevichi, Yudinovo, Pushkari). In: Epigravettian sites of middle Dnipro region. Archaeological Almanac, № 31, Publisher Oleg Filuk, Kyiv, pp. 99-116 (in Russian).

Gvozdover, M.D., 1947. Paleoliticheskaya stoyanka "Bugorok". K soobscheniyam o dokladah, polevikh issledovaniyah Instituta Istorii Mater'yalnoi Kultury, $\mathrm{XV}$, Moscow-Leningrad: AN SSSR (in Russian).

Haesaerts, P., Borziak, I., Chirica, V., Damblon, F., Koulakovska, L., Van der Plicht, J., 2003. The east Carpathian loess record: a reference for Middle and Late Pleniglacial stratigraphy in Central Europe. Quaternaire 14 (3), 163-188.

Haynes, G., 1991. Mammoths, Mastodonts and Elephants, Biology, behavior and the Fossil record. Cambridge Press, Cambridge. 
Hoffecker, J. F. 2002. Desolate Landscapes: Ice-Age Settlement in Eastern Europe. Rutgers University Press, New Brunswick (NJ).

lakovleva L., 2005. Les parures en coquillages au Paléolithique supérieur récent dans les territoires de peuplement du bassin du Dniepr, Archemetriai Muhely. Elektronikus folyoriat, 4 : 26-37.

Khlopachev, G.A., Gribchenko, Yu.N., Sapelko, T.V. 2013. Paleolithic site Eliseevichi 1: results of the field investigations of 2010 - 2011//Radlovskiy collection of articles. Scientific researches and scientific projects of MAE RAN in 2012. SaintPetersburg, pp. 80-90.

Khlopachev G.A, Grigorieva G.V., Kulkova M.A., Sablin M.V., 2006. Issledovaniya verhnepaleoliticheskogo poseleniya Yudinovo (2000-2005). In: Chistov, Y.K. (Eds.), Radlovskie chteniya. Lema, Saint-Petersburg, pp. 269-274 (in Russian).

Khlopachev G.A, Kulkova, M.A., 2007. Stoyanka Bugorok (Pushkari 9): geologirskaye karacteristika i vozrast// Radlovski sbornik. Naunye issledovanie I museinie proiektu. MAE RAN, pp. 226-231 (in Russian).

Khlopachev, G.A., 2014. Absolute and relative age of site Bugorok: geological,environmental and archaeological data. In: Epigravettian sites of middle Dnipro region. Archaeological Almanac, № 31, Publisher Oleg Filuk, Kyiv, pp. 81-98 (in Russian).

Khlopachev G.A., 2006. Les industries des ivoires du Paléolithique supérieur de l'Europe orientale. Saint-Petersburg, Nauka (en russe).

Khlopachev, G.A., 2001. Mammoth tusk processing using the knapping technique in the Upper Paleolithic of the Central Russian Plain. In: The World of Elephants, International Congress, Rome, pp. 444-447.

Kuzmina, I. E., Sablin, M.V., 1993. Arctic foxes of the Late Pleistocene from the Upper Desna River. In: Baryshnikov, G.F., Kuzmina, I.E. (Eds.), Materialy po mezozoiskoi i cainozoiskoi istorii nazemnykh pozvonochnykh. Trudy Zoologicheskogo Instituta RAN, St. Petersburg, 249, 93-104 (in Russian).

Klein R., 1973. Ice-Age Hunters of the Ukraine. University of Chicago Press, Chicago.

Laws, R.M., 1966. Age criteria for the African elephant Loxodonta a. Africana. East African Wildlife Journal, 4: 1-37.

Lázničková-Galetová, M. 2012. Données technologiques sur la gravure en ivoire de mammouth à l'Épigravettien : l'exemple du site de Mezin (Ukraine). In : Clottes, J. (dir.), L'art pléistocène dans le monde / Pleistocene art of the world / Arte pleistoceno en el mundo, Actes du Congrès IFRAO, Tarascon-sur-Ariège, septembre 2010 -Symposium «Art mobilier pléistocène», pp. 1311-1319

Legendre S., 1986. Analysis of mammalian communities from the late Eocene and Oligocene of southern France. Palaeovertebrata, 16 (4): 191-212.
Lyman, R. L., 2008. Quantitative Paleozoology. Cambridge University Press, Cambridge.

Montuire, S., 1994. Communautés de mammifères et environnements: l'apport des faunes aux reconstitutions des milieux en Europe depuis le Pliocène et l'impact des changements climatiques sur la diversité. Unpublished Ph.D. dissertation, University of Montpellier II, 128pp.

Nuzhnyi, D., 2006. The Latest Epigravettian Assemblages of the Middle Dnieper Basin (Northern Ukraine). Archaeologia Baltica, 7, 58-93.

Palombo, M.R., Giovinazzo C., 2004. What do cenograms tell us about the mammalian palaeoecology?. Senckenberg Research Institute and Natural History Museum.

Parmenter, R.P. and MacMahon, J.A., 2009. Carrion decomposition and nutrient cycling in a semiarid shrub-steppe ecosystem. Ecological Monographs, 79: 637-661.

Pidoplichko, I.G., 1969. Pozdnepaleoliticheskiye zhilischa is kostei mamonta na Ukraine. Naukova Dumka, Kiev (in Russian).

Pidoplichko, I.G., 1947. Paleolitichna stoyanka Chulativ I. Paleolit i Neolit Ukraini, 1: 123-153 (in Russian).

Pitulko, V.V, Pavlova, E.Y. and Nikolskiy, P.A., 2015. Mammoth ivory technologies in the Upper Palaeolithic: a case study based on the materials from Yana RHS, Northern Yana- Indighirka lowland Arctic Siberia. World Archaeology, 47 (3): 333-389.

Polikarpovich, K. M. 1968. Palaeolithic of the Upper Dnieper. Minsk. (in Russian)

Poplin, F., 1976. Remarques théoriques et pratiques sur les unités utilisées dans les études d'ostéologie quantitative, particulièrement en archéologie préhistorique. IXe Congrès UISPP, Nice, pp. 124-141.

Rountrey, A.N., Fisher, D.C., Tikhonov, A.N., Kosintsev, P.A., Lazarev, P.A., Boeskorov, G., Buigues, B., 2012. Early tooth development, gestation, and season of birth in mammoths. Quaternary International, 255: 196-205.

Sablin, M.V., Khlopachev, G.A., 2002. The earliest Ice Age dogs: Evidence from Eliseevichi. Current Anthropoly, 43: 795-799.

Sablin, M.V., Khlopachev, G.A., 2001. Sabaki iz verchnepaleolitieskogo pocelenie Eliseevichi 1. Stratum plus 1: 393-397 (in Russian).

Sablin, M.V., 2014. Epigravetski pam'iatki sered'nogo podniprov'je, Epigravetski. Paleontolologia stoyanki loudinovo : novie faktu. Analiz Interpretatsie, pp. 133-149 (in Russian).

Sablin, M.V.,1994. Late Pleistocene arctic fox (Alopex lagopus rossicus) from Kostenki in Voronezh Region. In: Kuzmina, I.E., Baryshnikov, G.F. (Eds.), Chetvertich naya fauna Severnoi Evrasii. Trudy Zoologicheskogo Instituta RAN, ,St. Petersburg, 256: 59-68 (in Russian).

Sapelko,T.V., 2014. Palynology of Late Paleolithic's archeological sites in the Desna river region. 
In: Epigravettian sites of middle Dnipro region. Archaeological Almanac, № 31, Publisher Oleg Filuk, Kyiv, pp. 117-132 (in Russian).

Semenov, S. A., 1957. Pervobitnaya technika 54. Moskow-Leningrad: Academy of Sciences SSSR (in Russian).

Sergin V.Ya., 2003. Suponevo: general information. Dwelling remains. Rossijskaâ arheologiâ, 2: 55-16.

Schemnitz, S.D. 2005. Capturing and handling wild animals. In : Braun, C.E. (Ed.), Techniques for wildlife investigations and management,. The Wildlife Society, Bethesda, USA, p. 239-285.

Shovkoplias, I.G., 1965. Mezinskaya stoyanka. Kiev: Naukova Dumka (in Russian).

Shovkoplias, I.G., 1952. Kistyani virobi Suponevskoi Paleolitichnoi styanki. Arheologiya VI: 81-94.

Shovkoplias, I.G., 1951. Zhitla Suponevs'koi Paleolitichnoi stoyanki. Arheologiya V: 127-142 (in Russian).

Shovkoplias, I.G., 1950. Suponevskaya Paleolitichna stoyanka. Arheologiya IV: 177-183.

Svezhentsev, Yu.S., Popov, S.G., 1993. Late Paleolithic chronology of the east European plain. Radiocarbon 35 (3): 495-501.

Soffer, O., 1985a. The upper paleolithic of the central russian plain. Academic Press, Orlando.

Soffer, O., 1985b. Exchange networks. In: Price, T.D., Brown, J.A. (Eds.), Prehistoric Hunter-Gatherers: The Emergence of Cultural Complexity. Academic Press, San Diego.

Stupak D.V., 2011. Explorations of Epigravettian Sites in the South of the Middle Desna Area. In: Tolochko, P.P. (Ed.), Ukrainian archaeology. Institute or archaeology of the National Academy of Sciences of Ukraine, Kiev, pp. 10-25.

Velichko, A.A., 1961. Region of the Dnieper glaciation (beyond the limits of the Moscow ice sheet). Relief and Quaternary stratigraphy. In: Markov, K.K. (Ed.), Relief and Quaternary Stratigraphy of the Northwestern Russian Plain. The USSR Academy of Sciences Press, Moscow, pp. 173-207 (in Russian).

Velichko, A.A., Grekhova, L.V., Gribchenko, Y.N., Kurenkova, E.I., 1997. Early Man in the extreme environmental conditions. Eliseevichi site. XVth Congress INQUA (Durban, south Africa, 1999). Rusian Academy of sciences-Institute of geography, State historical Museum, Moscow, (in Russian).

Velichko, A.A., Grekhova, L.V., Gubonina, S.P., Kurenkova, E.I., Udartsev, V.P., Halcheva, T.A, 1981. Timonovskiye stoyanki. Arheologiaya I paleogeografiya pozdnego Paleolita Russkoi ravnini, Nauka, pp. 69-77.

Velichko, A.A.,Grekhova, L.V., Gubonina,Z.P., 1977. Environmental conditions of existence of humans of Timonovka sites. Moscow: Nauka, 142 (in Russian).

Voevodski, M.V. 1929. Timonovka Palaeolithic site. Russkii Antropologicheskii zhurnal XVIII (1-2): 59-70 (in Russian).

Voevodski, M.V. 1940. Rezul'taty rabot Desninskoi eskpeditsii po izucheniyu Paleolita (1936-37). Byulleten'Komissii po Izucheniyu Chetvertichnogo Perioda 6-7: 54-57.

Voevodski, M.V., 1952a. Stoyanka Bugorok. Ucheniye Zapiski Moskovskogo Gosudarstvennogo Universiteta 158: 87-100.

Voevodski, M.V., 1952b. Paleoliticheskaya stoyanka Rabochii Rov (Chulatovo II). Ucheniye Zapiski Moskovskogo Gosudarstvennogo Universiteta 158: 101-132.

Zamiatnine, S.N., 1935. Les fouilles près du village de Gagarino (Le Haut-Don, la région centrale des terres noires). Bulletin d'informations de I'Académie d'Etat pour l'Histoire et la Culture matérielle CXVIII : 26-77 (in Russian). 
Demay L., Patou-Mathis M., Péan S., Khlopachev G.A., Sablin M.V.

\section{From mammoth to fox: functional identification of Eliseevichi 1 within Upper Pleniglacial settlements of the the Desna valley}

This study examines the faunal record in the Desna valley (Ukraine and Russia) during the end of the second part of the Upper Pleniglacial (20000 - 14000 BP). We have made the zooarchaeological study of the faunal remains of Eliseevichi 1 - 1935-36. The faunal spectrum is relatively restricted, typical of a cold and dry environment with the presence of Mammuthus primigenius, Rangifer tarandus, Canis lupus, Alopex lagopus rossicus and Ursus arctos. As expected we highlighted an important exploitation of mammoth related to ivory industry. However we also brought to light an intense exploitation of canid resources related to osseous industry and furskin activities. The interpretation of the site as base camp is questionable. We compared the zooarchaeological data obtained from Eliseevichi 1 faunal remains with other Upper Pleniglacial archaeological sites in the Desna valley. Our aim is to better understand the paleoecology of the Desna valley by the analysing of wildlife spectra and the human exploitation of fauna during the Upper Pleniglacial. Furthermore we can highlight the degree of specialization of human groups to exploit species, notably mammoth (meat, bones, ivory) and carnivores (fur, bones). These comparisons were made taking into account the preservation of the sites and the different types of occupations by human groups, to discuss on types of activities and storage of animal resources, in the Desna valley.

Демей Л., Пату-Матіс М., Пеан С., Хлопачев Г.А., Саблін М.В.

\section{Від мамонта до лисиці: функціональна ідентифікація пам'ятки Єлисеєвичі I в межах верхнього пленігляціалу на поселеннях басейну Десни.}

Дане дослідження вивчає фауністичні свідчення басейну Десни на території як України, так і Росії, впродовж другої половини верхнього пленігляціалу (20 000 - 14000 р. тому). Нами було проведено археозоологічне дослідження фауністичних решток пам'ятки Єлисеєвичі I за період 1935-36 рр. Фауністичний спектр відносно обмежений та типовий для холодного та посушливого клімату з наявними рештками шерстистого мамонта, північного оленя, вовка звичайного, песця та бурого ведмедя. Як і передбачалось, ми висвітлили питання використання мамонта задля отримання мамонтової кістки, а також активну експлуатацію собачих заради здобуття таких матеріалів як кістка та хутро. Питання інтерпретації стоянки як базового табору все ж ставиться під сумнів. Проаналізувавши розмаїття дикої природи та використання людиною фауни впродовж верхнього пленігляціалу, ми порівняли археозоологічні дані фауністичних решток отриманих зі стоянки Єлисеєвичі I 3 даними інших стоянок басейну Десни з метою кращого розуміння палеоекологічної ситуації регіону. Крім того, ми можемо висвітлити ступінь спеціалізації людських груп відносно експлуатації видів, особливо мамонтів (м'ясо, кістки, мамонтова кістка) та хижаків (хутро, кістка). Порівняння було здійснене з урахуванням збереженості пам'яток та відповідно до роду занять людських груп, задля обговорення видів активності та збереження тваринних ресурсів в басейні Десни. 

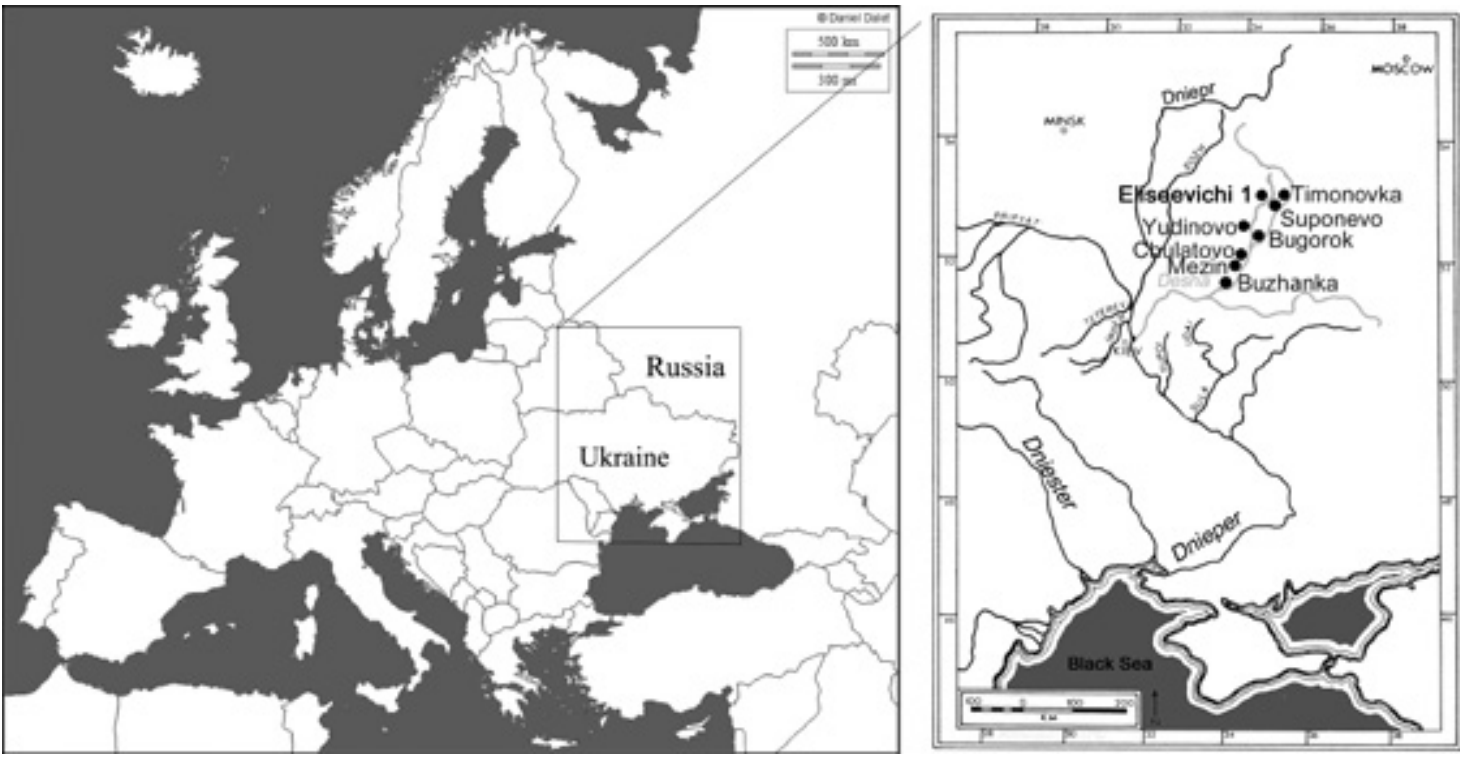

Fig. 1. Location of Eliseevichi 1 and the other sites of the Desna river valley.
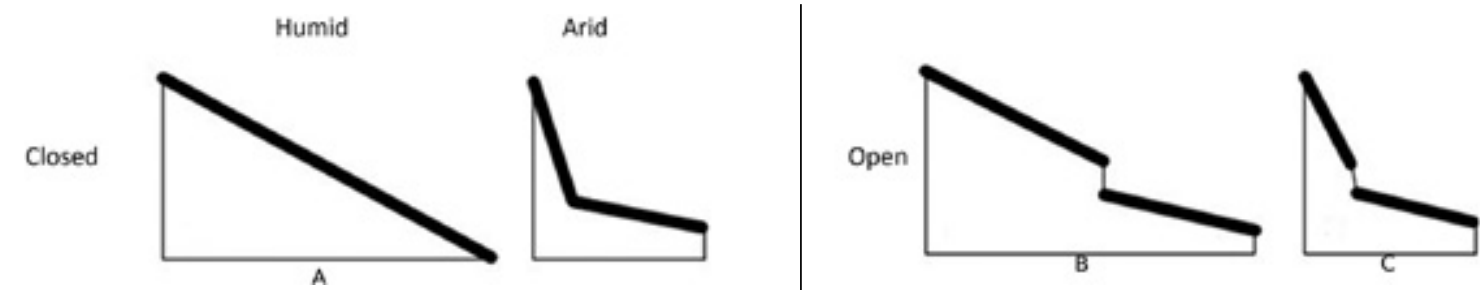

Fig. 2. Cenogram interpretations. A : forest type ; B : plain type ; $:$ steppe type (Legendre, 1986).

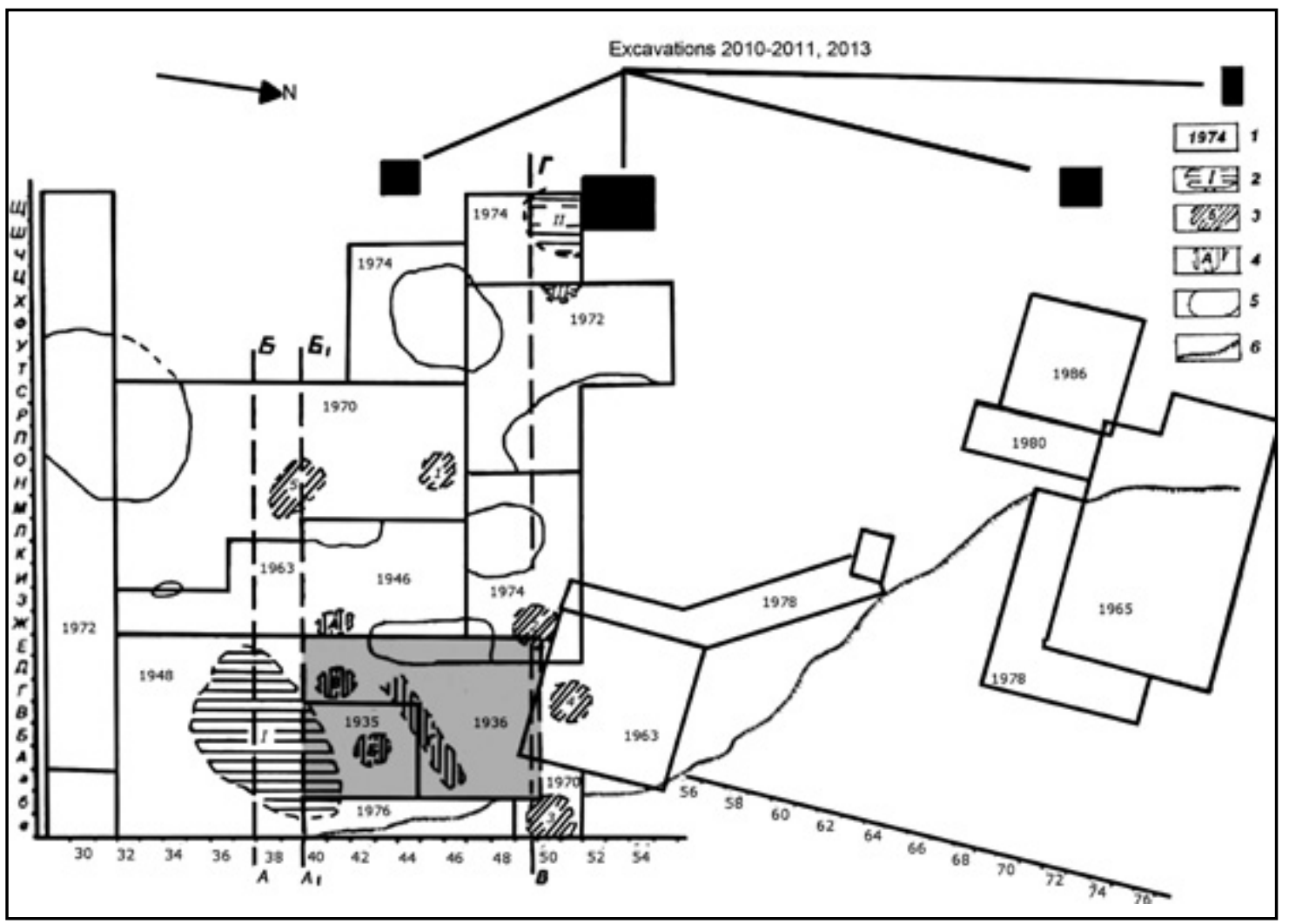

Fig. 3. Plan of the excavations, Eliseevichi 1 after Grekhova (In Velichko et al., 1997) and G.A. Khlopachev's data. 1: years of excavations; 2 : accumulations of bones and charcoals; 3 : dug pits and large concentrations of bones; 4: A: storage pits - Б-B- : accumulations of mammoth skulls - Г: frost crack (after Polikarpovich) ; $5:$ pit ; 6 : brovka (edge). 


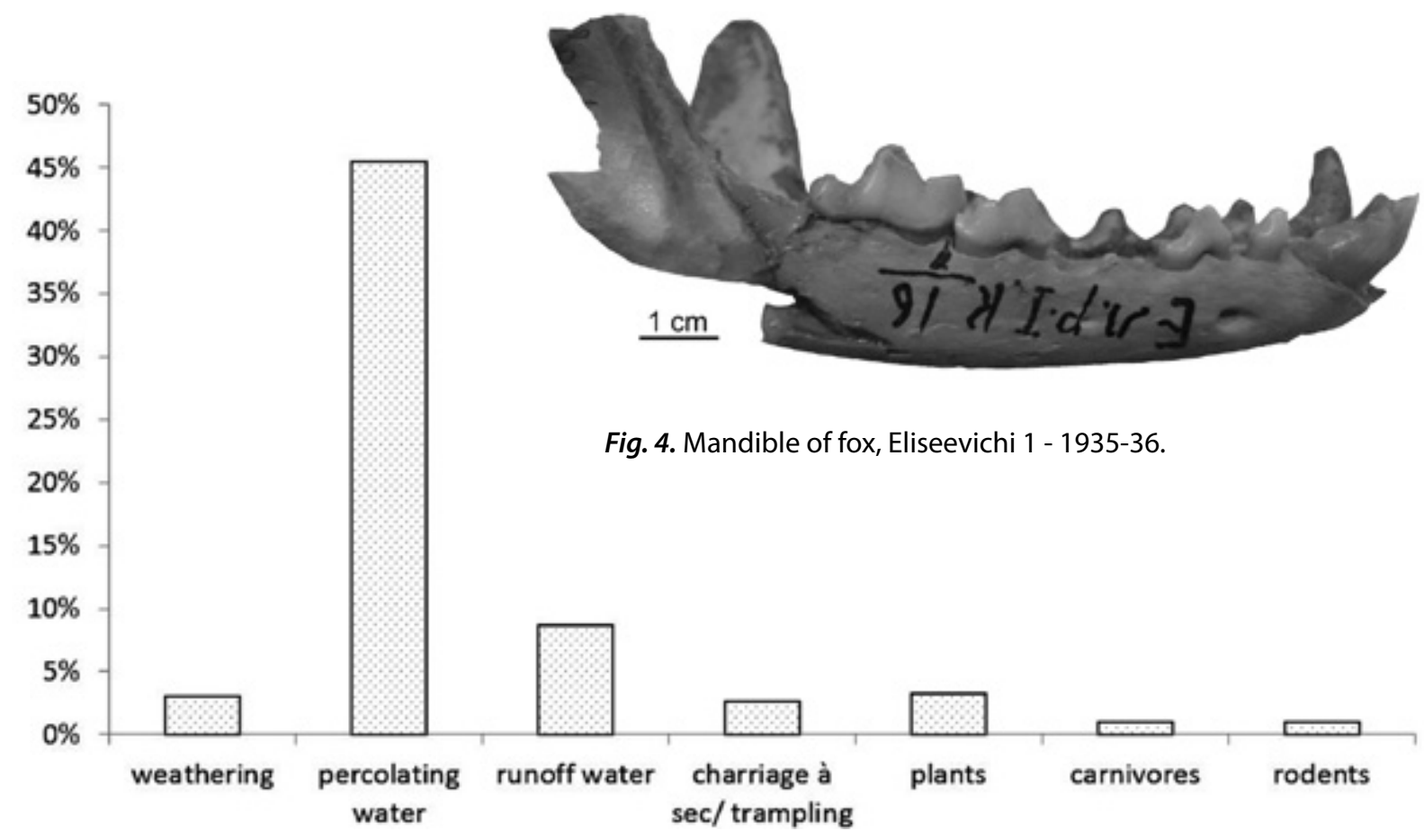

Fig. 5. Involved climato-edaphic and biological taphonomical agents, in \%NRt, Eliseevichi 1 - 1935-36.

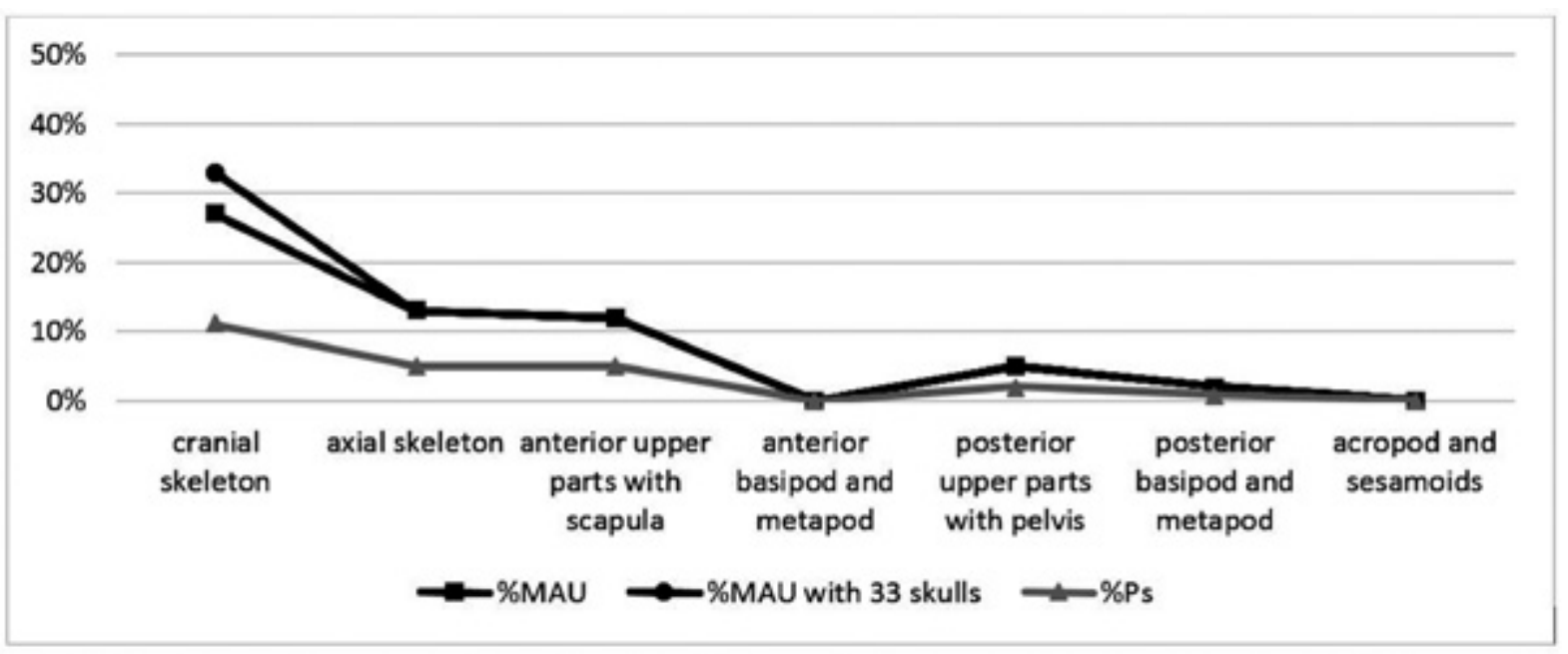

Fig. 6. Skeletal preservation by anatomical parts in percentage survivorship and in percentage of minimal animal unit of M. primigenius, Eliseevichi 1 - 1935-56. 

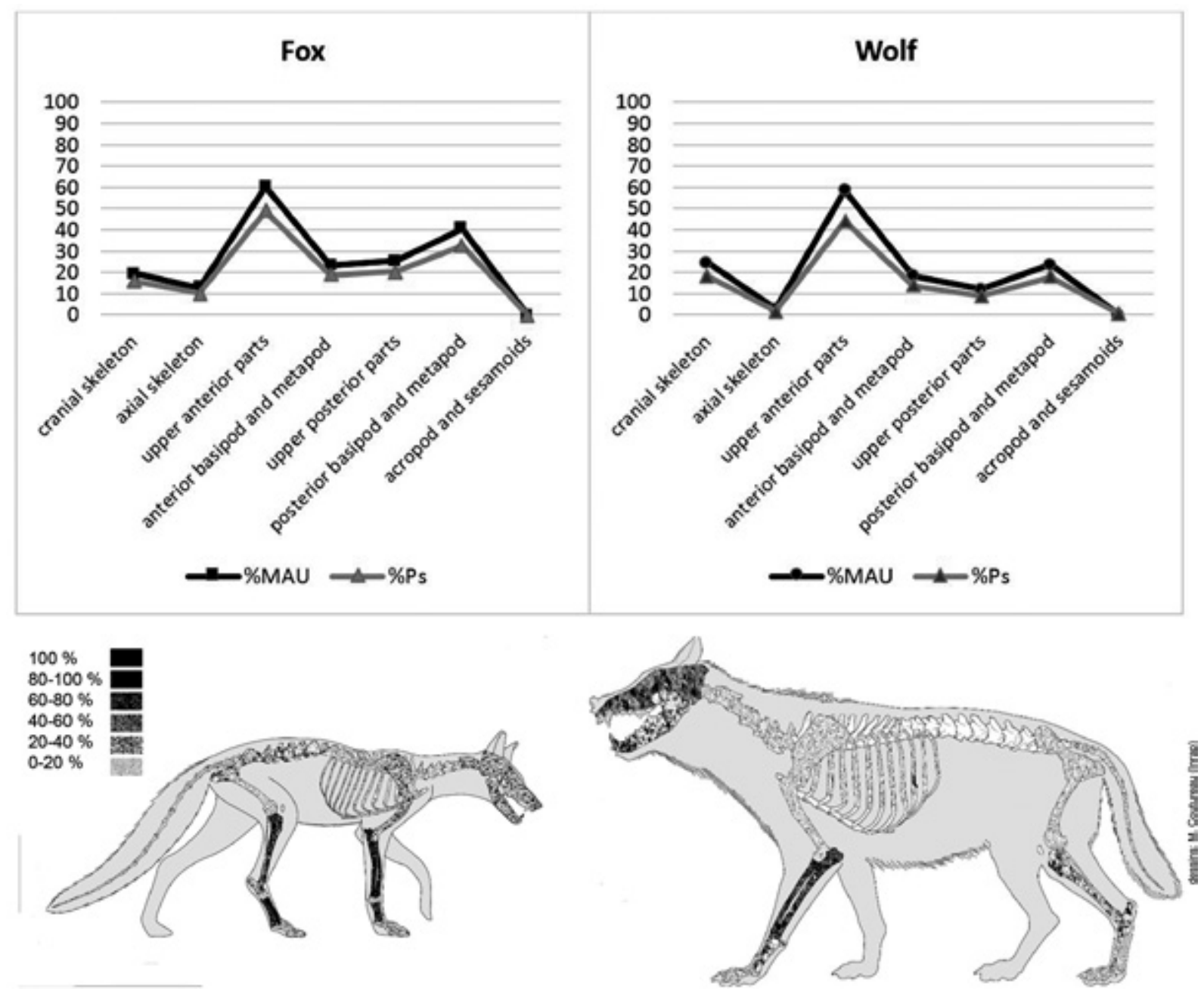

Puc. 7. Skeletal preservation by anatomical parts in percentage survivorship and in percentage of minimal animal unit of Canids, Eliseevichi 1 - 1935-56. 


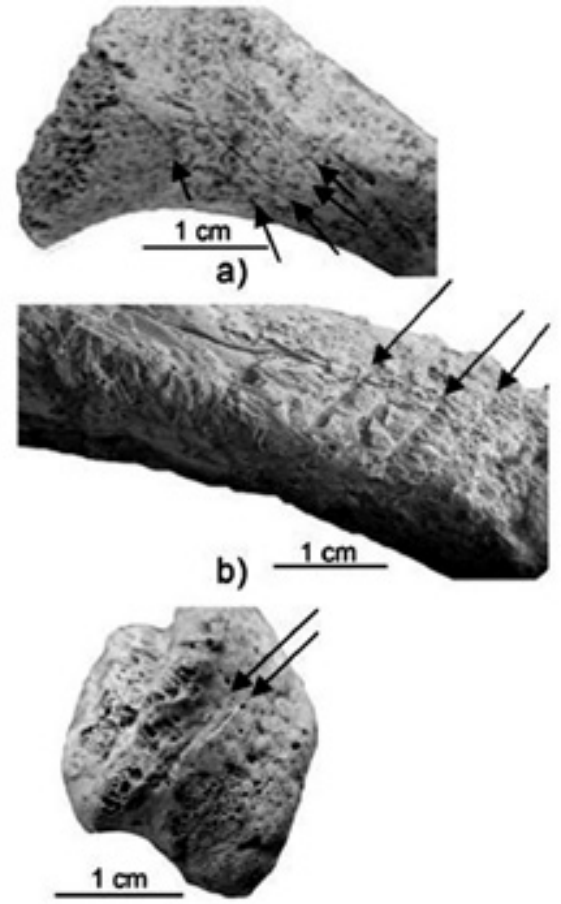

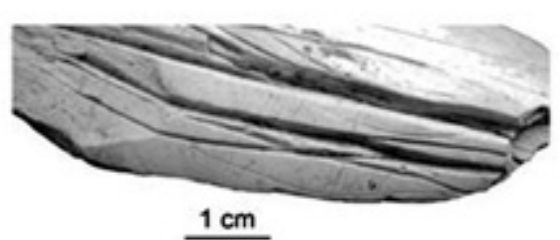

d)

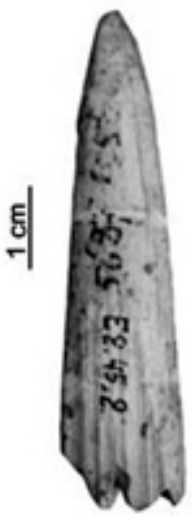

f)

g)

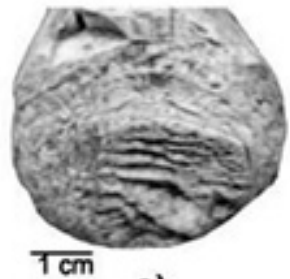

e)

c)

Puc. 8. Butchering cutmarks on mammoth bones, Eliseevichi 1 - 1935-36. a) juvenile mammoth rib with cutmarks of disarticulation ; b) tibia of juvenile mammoth with cutmarks of defleshing ; c) phalanx with cutmarks of skinning, Eliseevichi 1 - 1935-36. d) longitudinal incisions ; e) circular transverse grooving ; f) point ; g) needle ; h) rectangular plate.

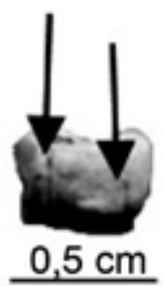

a)

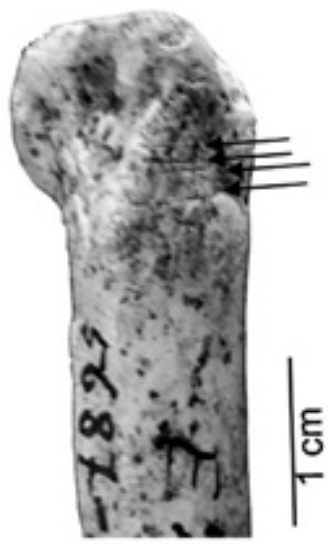

c)

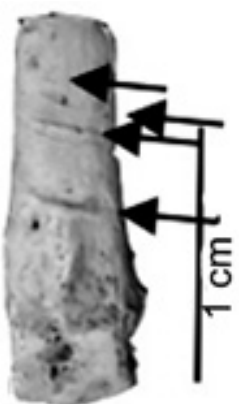

b)

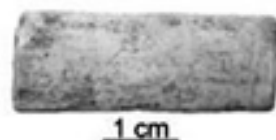

h) 


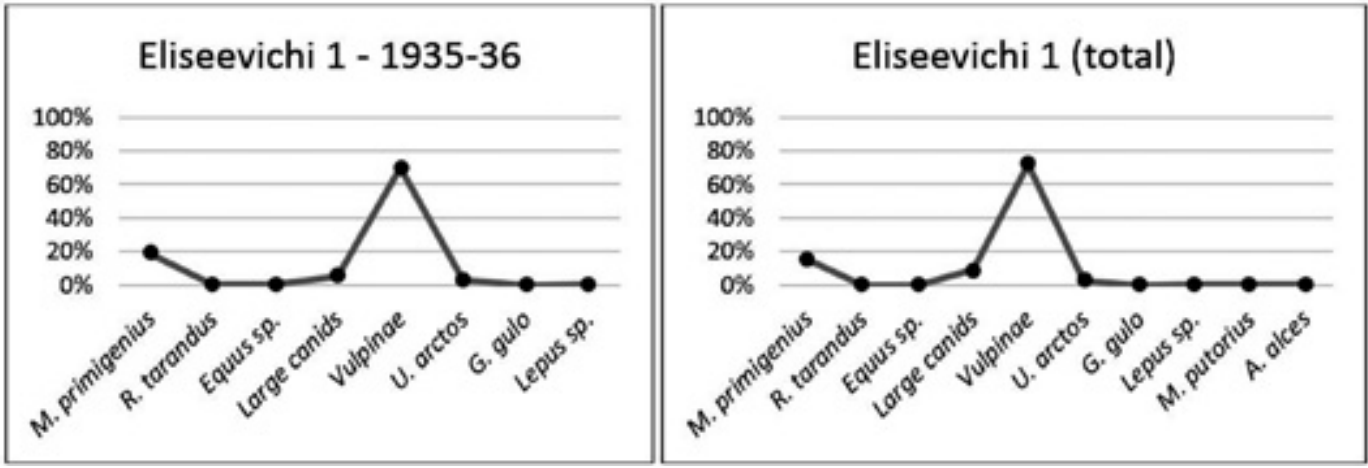

Puc. 10. Faunal representation in \%MNIc for Eliseevichi 1.
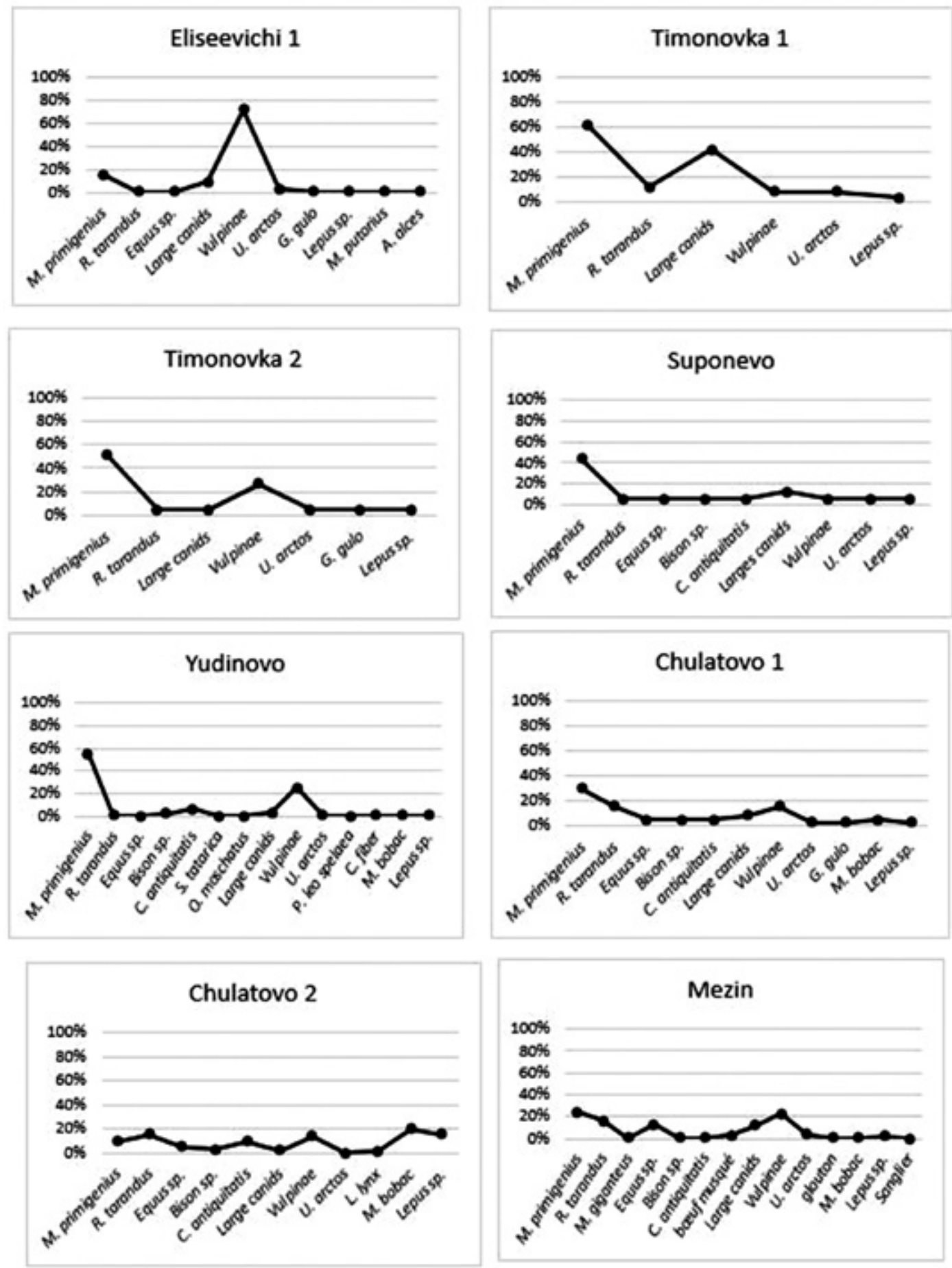

Puc. 11. Faunal representation in \%MNIc for the selected sites of the Desna river. 

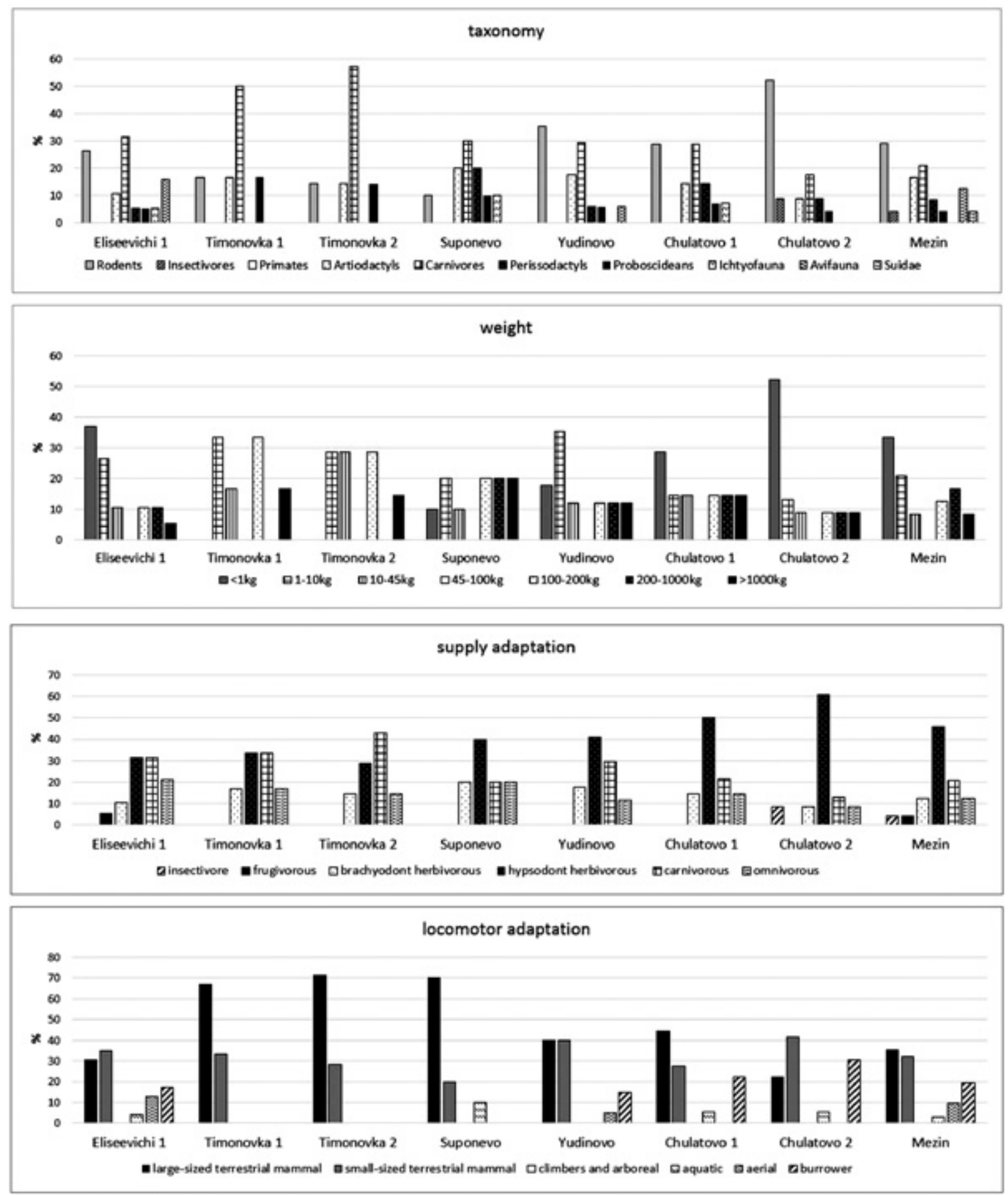

Puc. 12. Ecological histograms based on fauna from the selected sites of the Desna river valley, in percentage of number of species. 

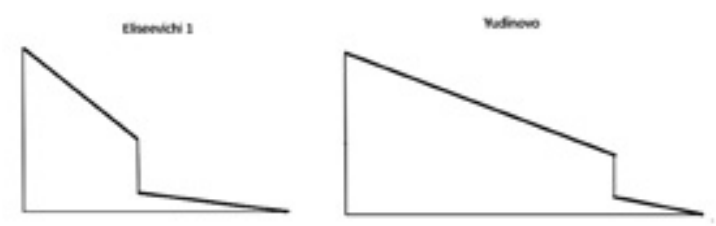

Puc. 13. Cenograms from the selected

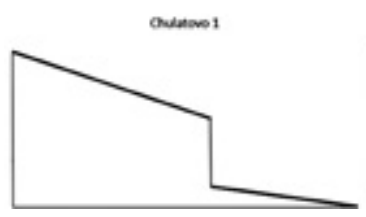

ondonos? sites of the Desna river valley.

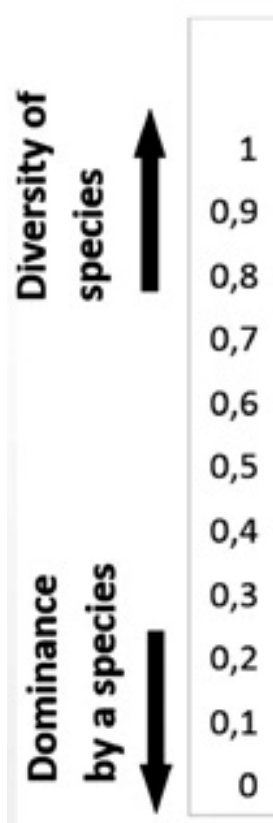

\section{Shannon's index}
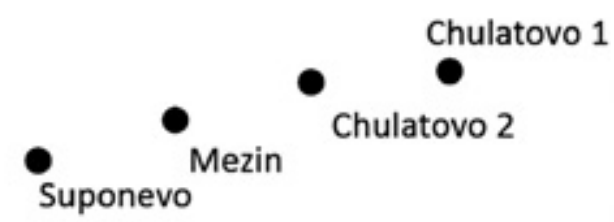

- Yudinovo

Timonovka 1

\section{Timonovka 2}

\section{Eliseevichi 1}

Puc. 14. Shannon's index of faunal diversity plotted for from the selected sites of the Desna river valley.

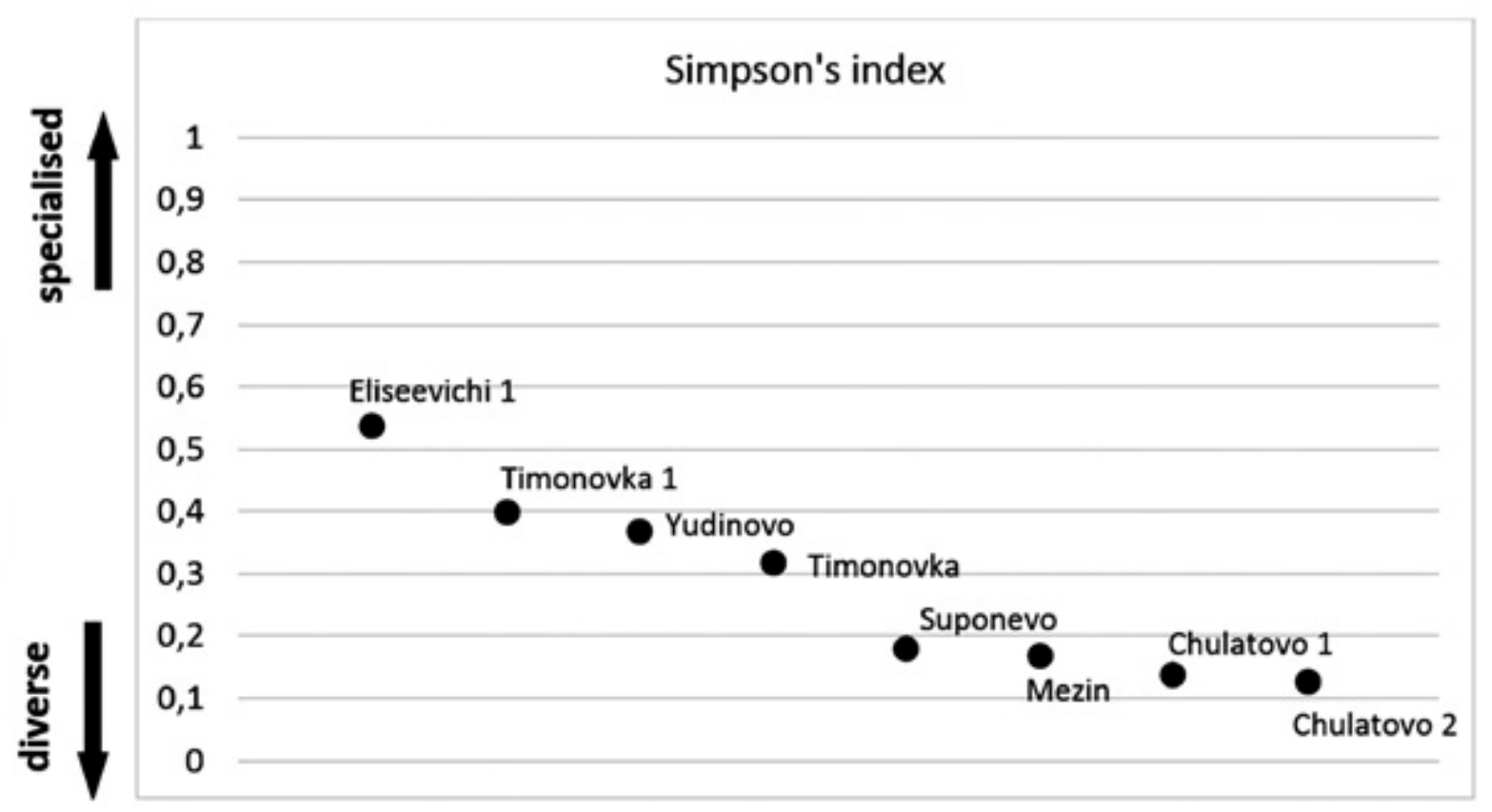

Puc. 15. Simpson's index of faunal diversity plotted for from the selected sites of the Desna river valley. 


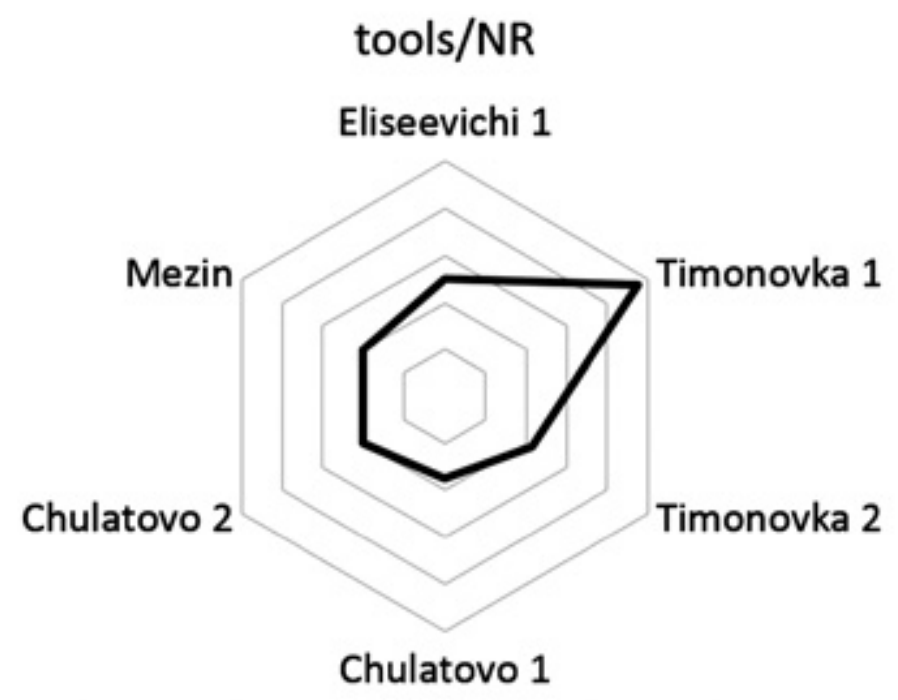

Puc. 16. Ratio of lithic remains and tools for the selected sites of the Desna valley.

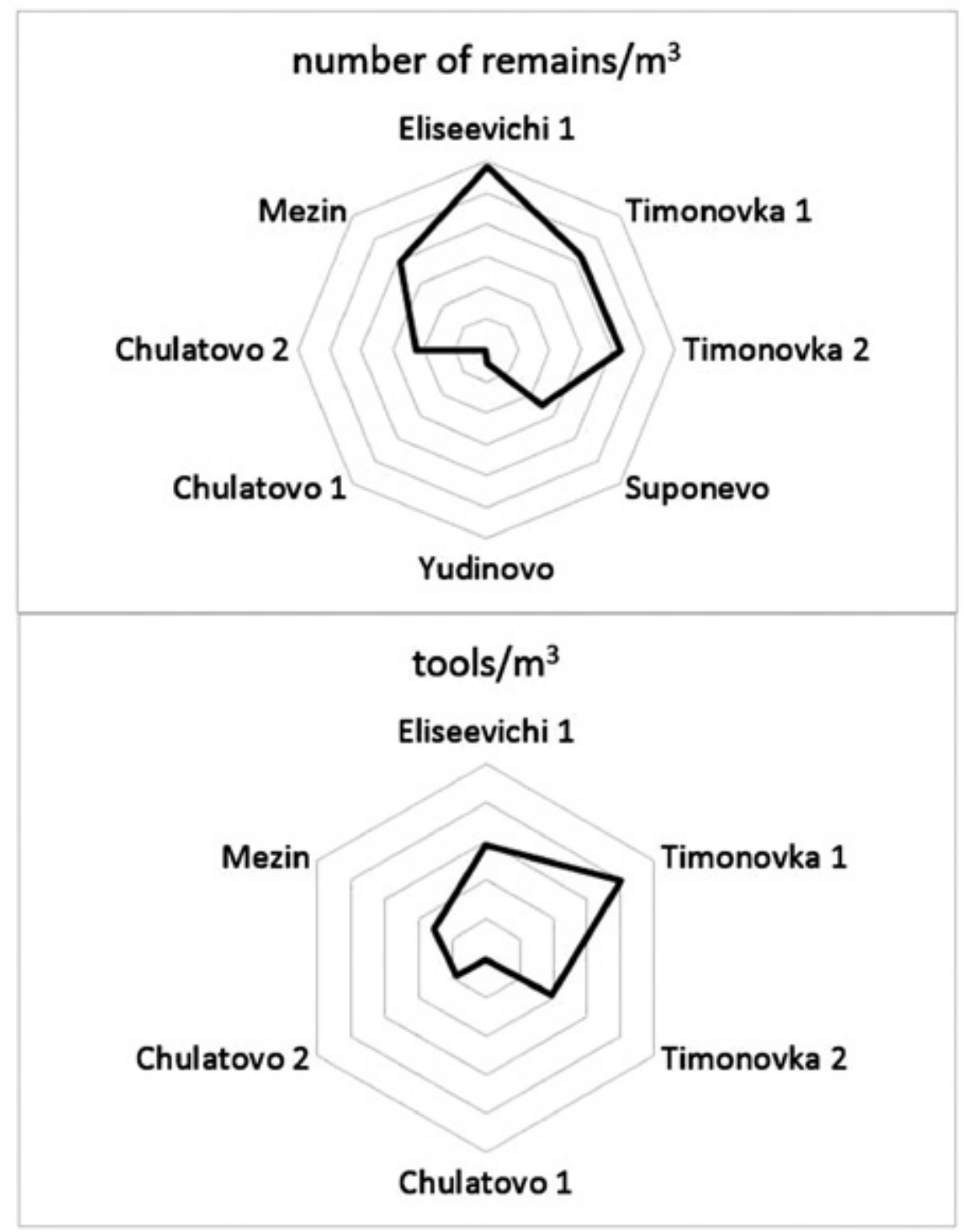

Puc. 17. Lithic density by $\mathrm{m} 3$ for the selected sites of the Desna valley. 


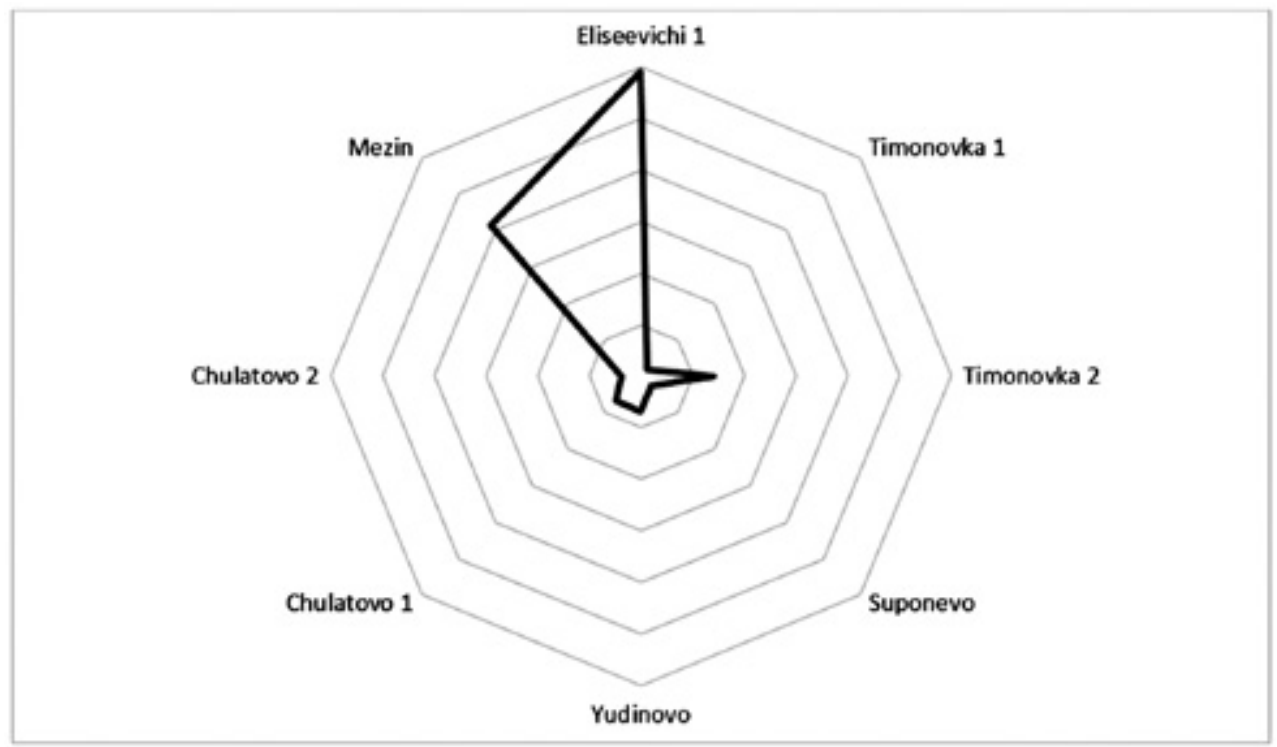

Puc. 18. Density of faunal remains in MNI by $\mathrm{m} 3$ in the selected sites of the Desna river valley.

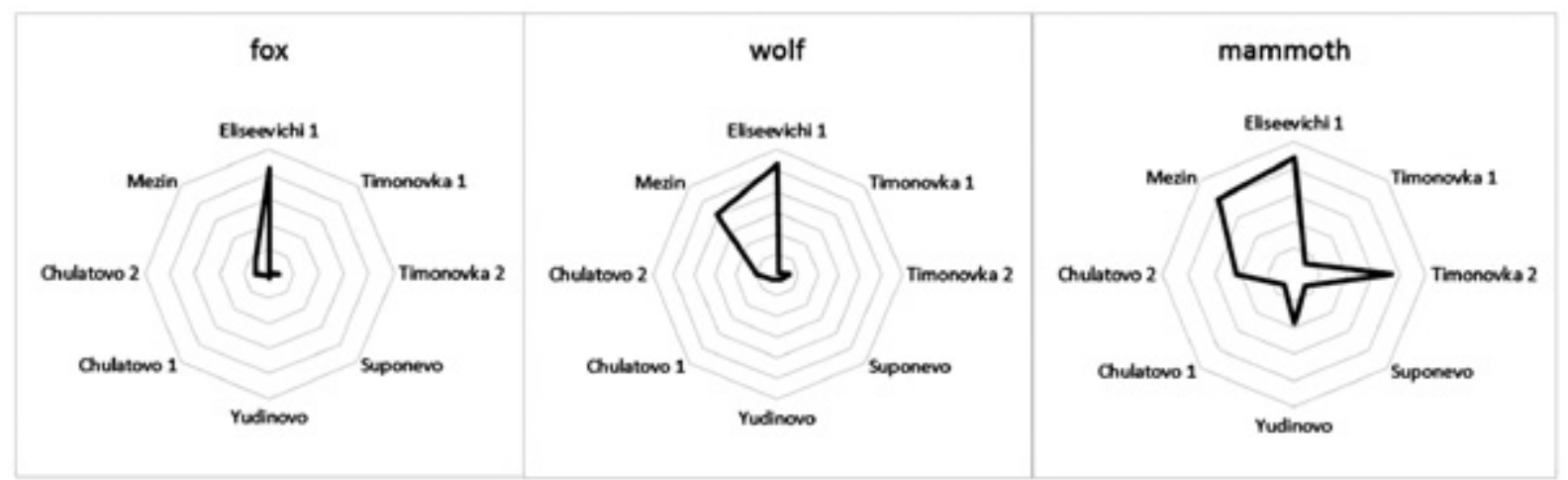

Puc. 19. Density of faunal remains in MNIc by $\mathrm{m} 3$ for the selected sites of the Desna river valley. 


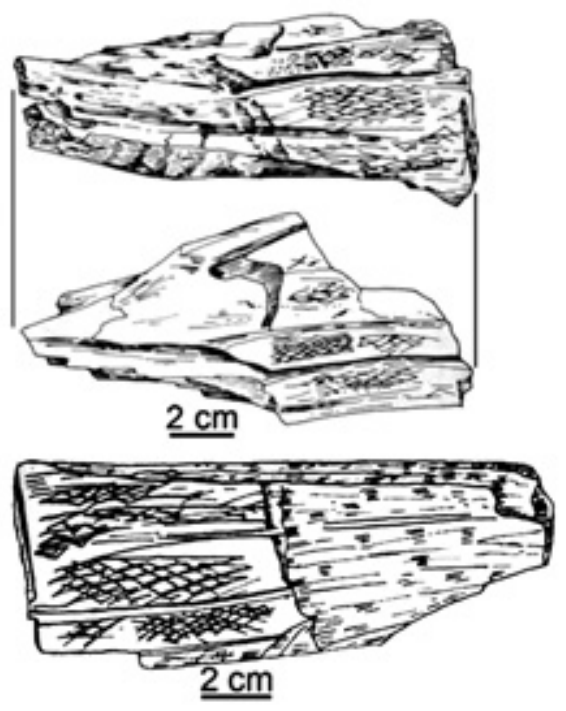

Timonovka 1
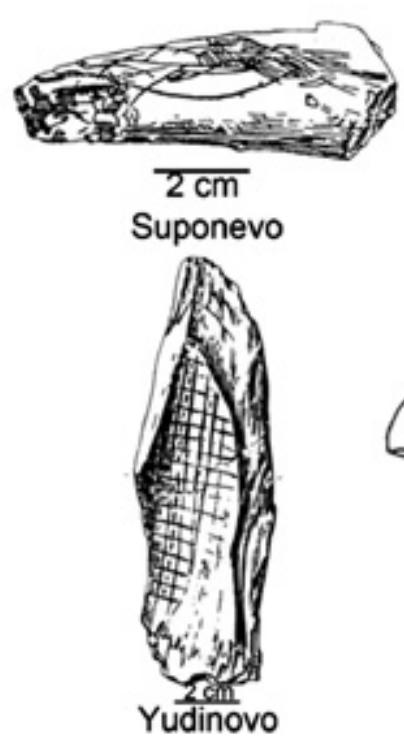
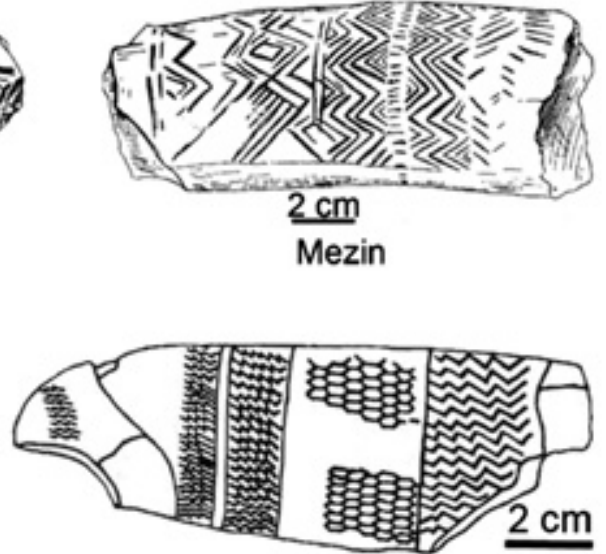

Eliseevichi 1

Puc. 20. Tusk fragments with working processes and decors of Eliseevichi 1 (Polikarpovich, 1968), Timonovka 1 (Velichko et al., 1977), Suponevo (Shovkoplias, 1952), Yudinovo (Polikarpovich, 1968) and Mezin (Shovkoplias, 1965).

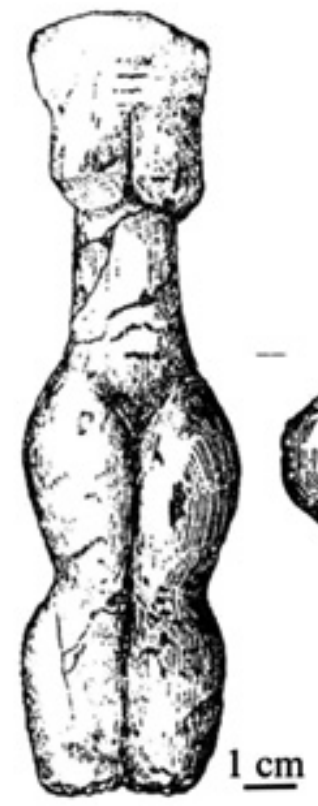

Eliseevichi 1

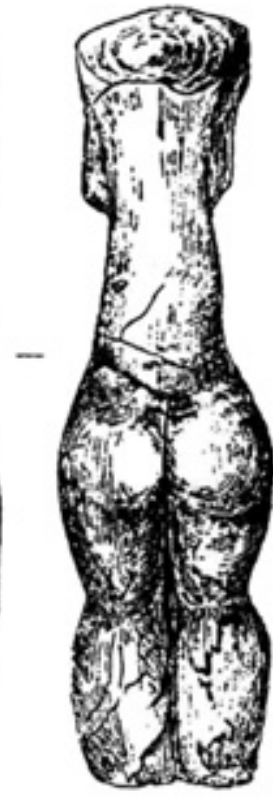

Yudinovo
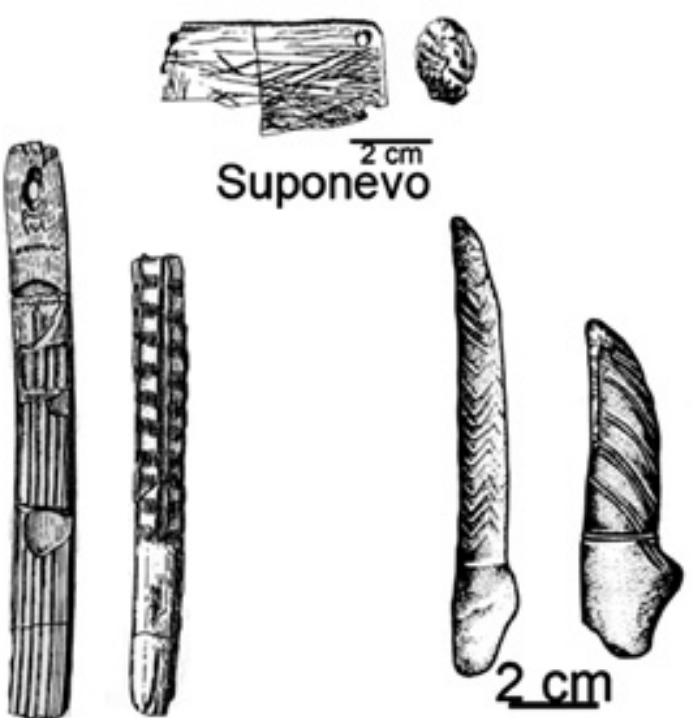

Mezin

Puc. 21. Ivory artefacts from Eliseevichi 1 (Abramova, 1962), Suponevo (Shovkoplias, 1952), Yudinovo (Abramova and Grigorieva, 1993) and Mezin (Shovkoplias, 1965). 

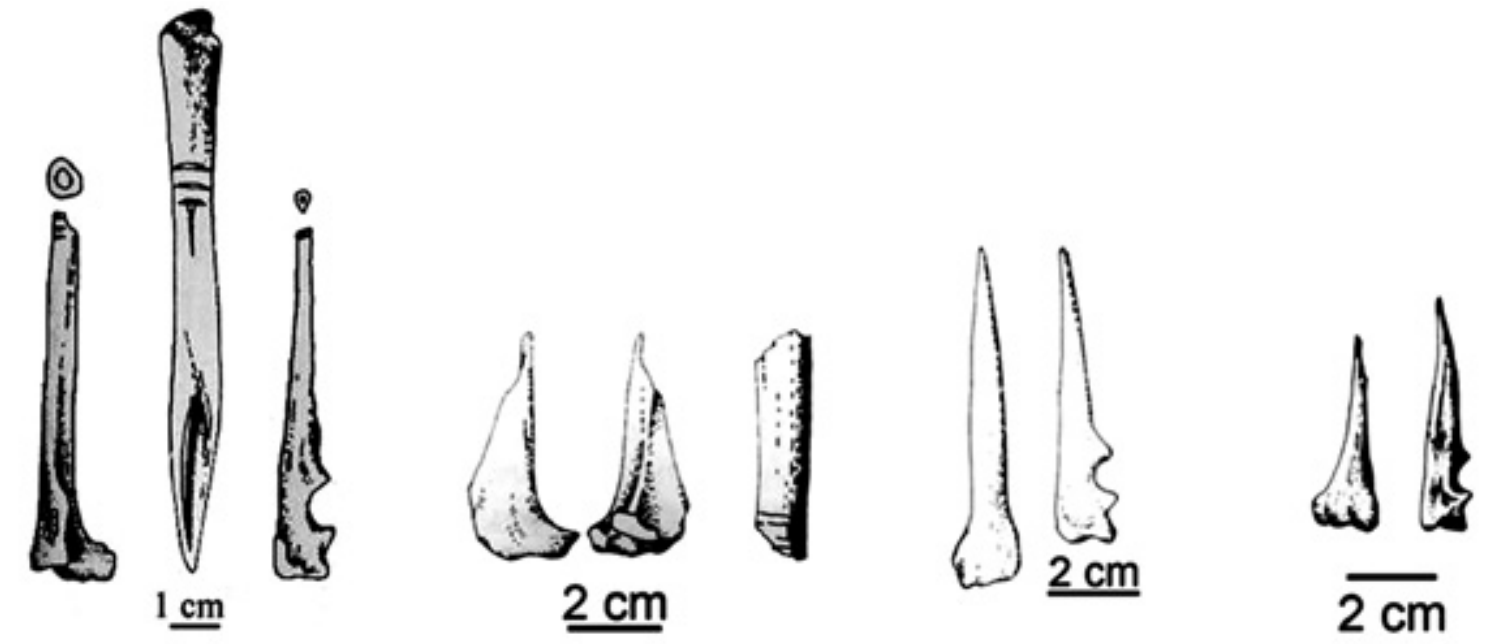

\section{Eliseevichi 1 Timonovka 1 Suponevo Mezin}

Puc. 22. Sawn and incised long bones of foxes from Eliseevichi 1 (Polikarpovich, 1968), Timonovka (Velichko et al., 1977), Suponevo (Shovkoplias, 1952) and Mezin (Shovkoplias, 1965).
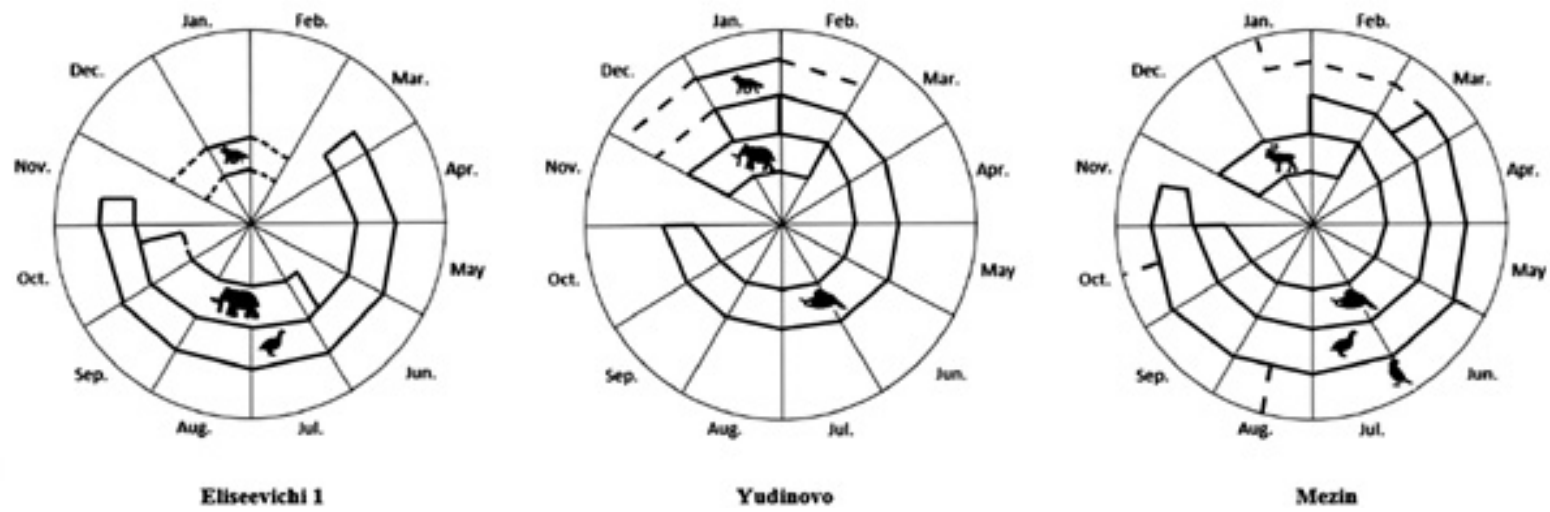

Puc. 23. Possible seasons of settlements. 


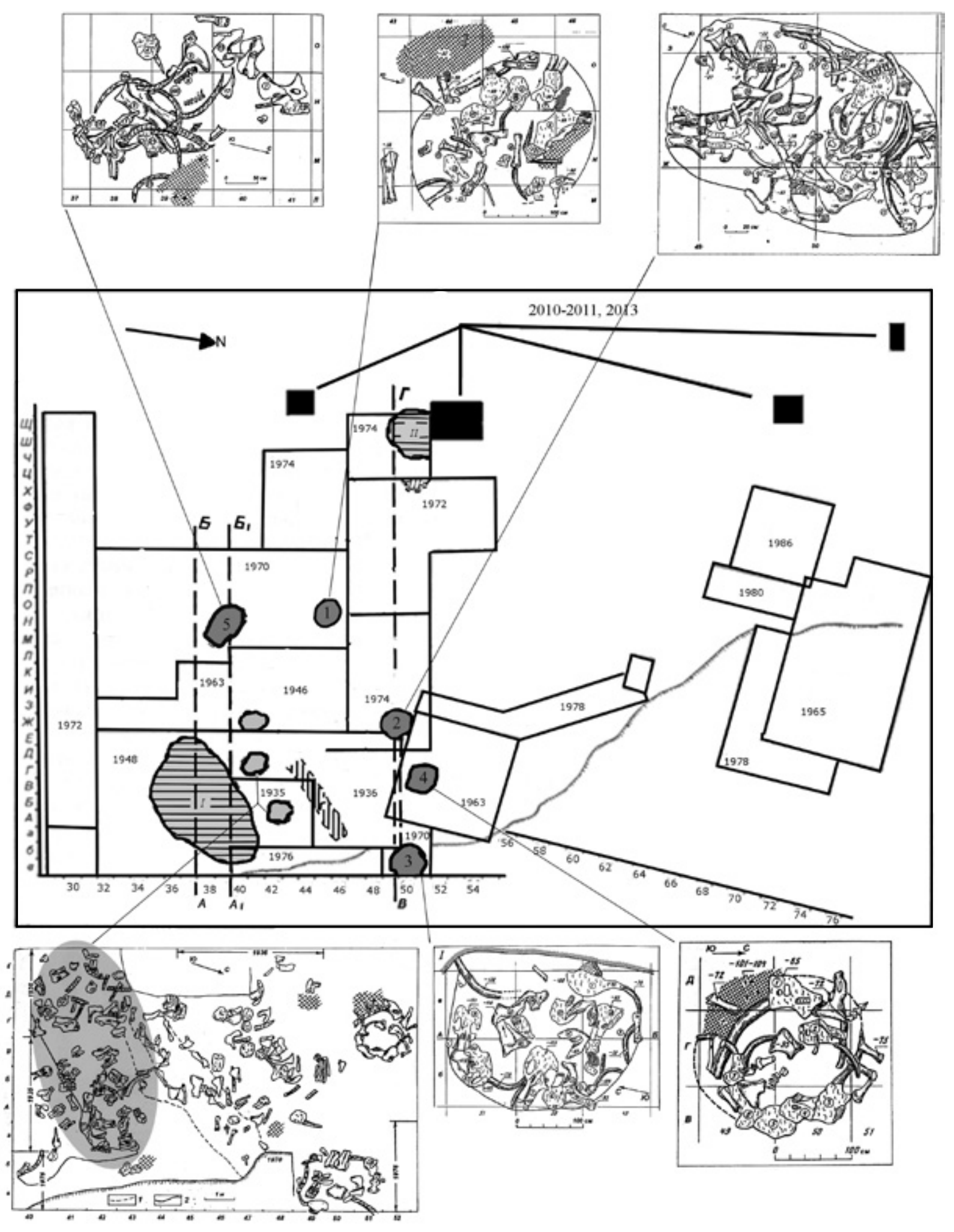

Puc. 24. Pits of Eliseevichi 1 (figures from Velichko et al., 1997). 